\title{
MC1R and the response of melanocytes to ultraviolet radiation
}

\author{
Francois Rouzaud $^{\mathrm{a}}$, Ana Luisa Kadekaro ${ }^{\mathrm{b}}$, Zalfa A. Abdel-Malek ${ }^{\mathrm{b}}$, \\ Vincent J. Hearing a,* \\ ${ }^{a}$ Laboratory of Cell Biology, National Cancer Institute, National Institutes of Health, \\ Building 37, Room 2132, Bethesda, MD 20892, USA \\ ${ }^{\mathrm{b}}$ Department of Dermatology, University of Cincinnati, College of Medicine, \\ Cincinnati, $\mathrm{OH} 45267$, USA
}

Received 7 June 2004; received in revised form 5 September 2004; accepted 30 September 2004

Available online 26 January 2005

\begin{abstract}
The constitutive color of our skin plays a dramatic role in our photoprotection from solar ultraviolet radiation (UVR) that reaches the Earth and in minimizing DNA damage that gives rise to skin cancer. More than 120 genes have been identified and shown to regulate pigmentation, one of the key genes being melanocortin 1 receptor $(M C 1 R)$ that encodes the melanocortin 1 receptor (MC1R), a seven-transmembrane G protein-coupled receptor expressed on the surface of melanocytes. Modulation of MC1R function regulates melanin synthesis by melanocytes qualitatively and quantitatively. The MC1R is regulated by the physiological agonists $\alpha$-melanocyte-stimulating hormone $(\alpha \mathrm{MSH})$ and adrenocorticotropic hormone (ACTH), and antagonist agouti signaling protein (ASP). Activation of the MC1R by binding of an agonist stimulates the synthesis of eumelanin primarily via activation of adenylate cyclase. The significance of cutaneous pigmentation lies in the photoprotective effect of melanin, particularly eumelanin, against sun-induced carcinogenesis. Epidermal melanocytes and keratinocytes respond to UVR by increasing their expression of $\alpha \mathrm{MSH}$ and $\mathrm{ACTH}$, which up-regulate the expression of MC1R, and consequently enhance the response of melanocytes to melanocortins. Constitutive skin pigmentation dramatically affects the incidence of skin cancer. The pigmentary phenotype characterized by red hair, fair complexion, inability to tan and tendency to freckle is an independent risk factor for all skin cancers, including melanoma. The $M C 1 R$ gene is highly polymorphic in human populations, and allelic variation at this locus accounts, to a large extent, for the variation in pigmentary phenotypes and skin phototypes (SPT) in humans. Several allelic variants of the $M C 1 R$ gene are associated with the red hair and fair skin (RHC) phenotype, and carrying one of these variants is thought to diminish the ability of the epidermis to respond to DNA damage elicited by UVR. The $M C 1 R$ gene is considered a melanoma susceptibility gene, and its significance in determining the risk for skin cancer is of tremendous interest. (C) 2005 Elsevier B.V. All rights reserved.
\end{abstract}

Keywords: Melanocortin 1 receptor (MC1R); Ultraviolet radiation (UVR); $\alpha \mathrm{MSH}$; Pigmentation; Melanocyte

\footnotetext{
* Corresponding author. Tel.: +1 301496 1564; fax: +1 3014028787.

E-mail address: hearingv@nih.gov (V.J. Hearing).
} 


\section{Contents}

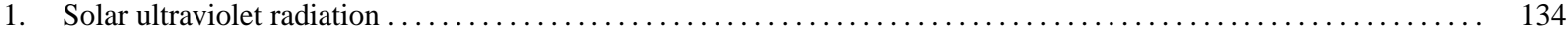

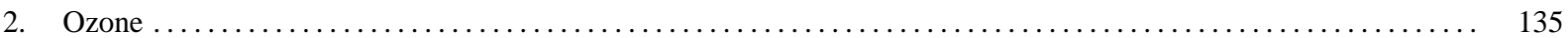

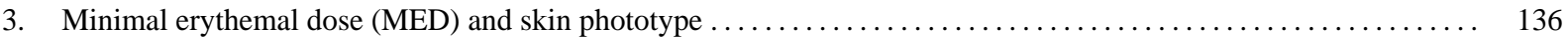

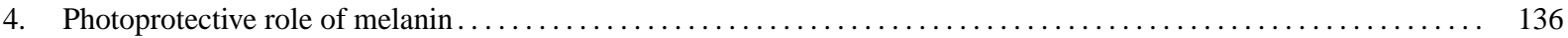

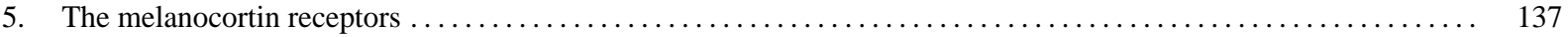

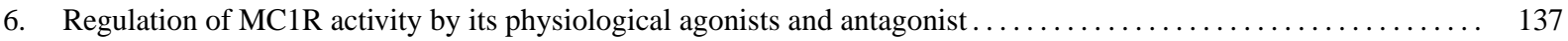

7. Human MC1R allelic variants: link to sun sensitivity and/or melanoma susceptibility $\ldots \ldots \ldots \ldots \ldots \ldots$

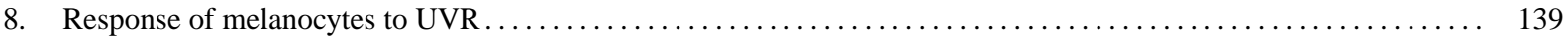

9. Response of MC1R to $\mathrm{UV} / \alpha \mathrm{MSH}$ with respect to the various genotypes/phenotypes $\ldots \ldots \ldots \ldots \ldots \ldots \ldots \ldots \ldots \ldots$

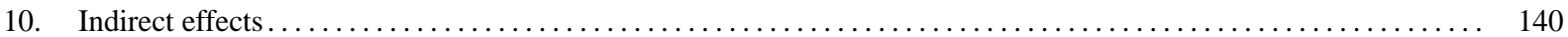

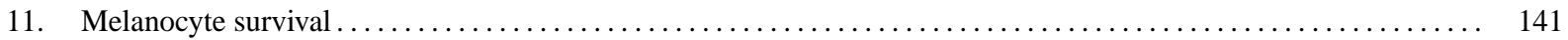

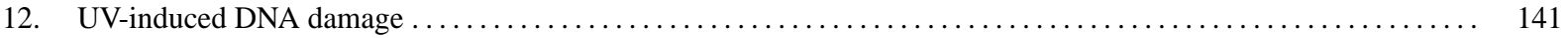

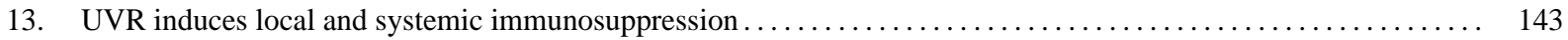

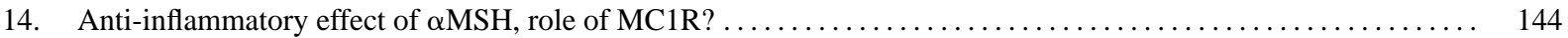

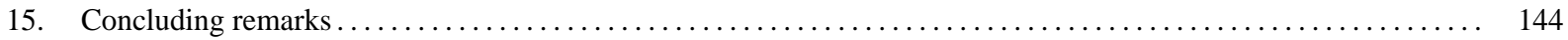

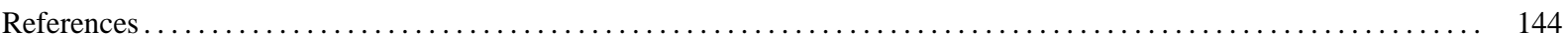

\section{Solar ultraviolet radiation}

The main etiological factor for skin cancer (basal and squamous cell carcinoma and melanoma) is sun exposure. Solar radiation that reaches the Earth is a complex physical entity that consists of a continuous spectrum of electromagnetic radiation that can be divided into three major regions: infrared (700-2000 nm) and visible (400-700 nm), which contribute equally to about $87 \%$ of total sunlight energy, and solar ultraviolet radiation (UVR) (200-400 nm), which comprises the remaining $13 \%$ [1].

In 1801, Johann W. Ritter, a German physicist, inspired by Herschel's [2] prior discovery of infrared radiation, conducted experiments with silver salts and a prism [3]. He projected a beam of sunlight through the prism, which split the beam into the colors of the spec- trum. He then exposed the salts to each color to see the outcome. The red caused a small change while the deep violet darkened the silver salts. Ritter placed salts in the lightless area just beyond the violet and it darkened with smoke. This was evidence of another waveform just barely higher than the violet of visible light. It is now known as ultraviolet (from the latin word "ultra" meaning beyond) or UVR.

The region representing UVR, the most significant region of sunlight with respect to skin cancer, lies in the range of $200-400 \mathrm{~nm}$, just above visible light at 400-700 nm [4]. UVR can be further subdivided into UVA (320-400 nm), UVB (290-320 nm with a peak at $305 \mathrm{~nm})$ and UVC (200-290 nm with a peak at $254 \mathrm{~nm}$ ) [5-8]. The UVC contribution to the development of skin cancers is considered negligible, since it is prevented from reaching the surface of the Earth by the 
atmospheric ozone layer that blocks UVR below about $300 \mathrm{~nm}$. Unlike UVC, UVA and UVB both reach the Earth's surface in amounts sufficient to cause harmful biological effects on the skin. It is estimated that $5 \%$ of solar UVR is UVB [9].

The spectral characteristics of solar radiations undergo shifts while traveling from the sun to the Earth's surface. Absorption in the spectral region below $85 \mathrm{~nm}$ is mainly due to $\mathrm{O}, \mathrm{O}_{2}, \mathrm{~N}$ and $\mathrm{N}_{2}$. The absorption above the stratosphere for the $85-200 \mathrm{~nm}$ is due to $\mathrm{O}_{2}$. When solar rays reach the stratospheric layer, ozone $\mathrm{O}_{3}$ absorbs the remaining solar UVR in the $200-288 \mathrm{~nm}$ wavelength range. Thus, essentially solar UVR shorter than $288 \mathrm{~nm}$ is absorbed by the Earth's atmosphere [10].

UV exposure varies continuously with the time of the day, the season of the year, the zenith angle of the sun, the cloud cover and the changes in reflecting surfaces. These uncertainties make the assessment of solar UVR impinging on human skin very difficult. For example, the total radiation reflected from grass is about 3\%, 20-30\% from sand, about 5\% from water and up to $90 \%$ from snow [10]. As the sun falls lower in the sky, the path length of the sun's UV rays through the atmosphere increases and as a consequence the intensity of UV reaching the Earth's surface decreases at all wavelengths, particularly those shorter than $320 \mathrm{~nm}$. The sun's UV rays are strongest in the 4-h period around local noon when 50-60\% of a summer's day UV is received. Exposure to the sun before 11 a.m. and again after 3 p.m. until the end of the day avoids most of the ambient available UV [11].

Since pure water is a very weak absorber of UVR, clouds, which are composed of either liquid or ice droplets, attenuate UV primarily by scattering. Clouds reduce UV intensity, although not to the same extent as infrared intensity. This is because water in clouds attenuates solar infrared much more than UV and so the risk of overexposure is increased because the warning sensation of heat is diminished.

\section{Ozone}

For over 50 years, chlorofluorocarbons (CFCs) were thought of as miracle substances. They are stable, nonflammable, low in toxicity and inexpensive to produce.
Over time, CFCs found uses as refrigerants, solvents, foam blowing agents, and in many other smaller applications. Other chlorine-containing compounds include methyl chloroform, a solvent, and carbon tetrachloride, an industrial chemical. Halons, extremely effective fire-extinguishing agents, and methyl bromide, an effective produce and soil fumigant, contain bromine. All of these compounds have atmospheric lifetimes long enough to allow them to be transported by winds into the stratosphere [12]. Because they release chlorine or bromine when they break down, they damage the protective ozone layer [13]. The ozone layer, measured in Dobson Units, is formed $100 \mathrm{~km}$ above the Earth's surface: $\mathrm{O}_{2}+\mathrm{UVC}=\mathrm{O}+\mathrm{O}$ and then, in the stratosphere $\mathrm{O}_{2}+\mathrm{O}=\mathrm{O}_{3}$. But when CFCs are exposed to UVR, the CFC molecules release atomic chlorine: $\mathrm{CFCl}_{3}(\mathrm{CFCs})+\mathrm{UV}=3 \mathrm{Cl}$. One chlorine atom can destroy over 100,000 ozone molecules. The net effect is to destroy ozone faster than it is naturally created $\mathrm{Cl}+\mathrm{O}_{3}=\mathrm{ClO}+\mathrm{O}_{2}$ and $\mathrm{ClO}+\mathrm{O}=\mathrm{Cl}+\mathrm{O}_{2}$ (from US Environmental Protection Agency www.epa. gov).

Recognition that CFCs are contributors to stratospheric chlorine levels and that stratospheric ozone depletion is a chlorine-catalyzed process [13] has led international authorities to mandate the phase-out of CFCs in 1996. Hydrochlorofluorocarbons and hydrofluorocarbons are being developed as substitutes for CFCs. This results in a much smaller half-life and lower ozone depleting potential for these products in comparison with CFCs [14]. In addition, research has shown that ozone depletion occurs over the latitudes that include North America, Europe, Asia, and much of Africa, Australia, and South America. Thus, ozone depletion is a global issue and not just a problem at the South Pole [15].

UVC rays are the strongest, most dangerous type of UV. Little attention has been given to UVC rays in the past since they are normally filtered out by the ozone layer and do not reach the Earth. However, thinning of the ozone layer and holes in the ozone layer are causing increased concern about the potential for UVC radiation exposure [16-20]. Concerns are also rising about the biologically harmful effects of less UVB being filtered by the depleted ozone layer $[15,21,22]$. Krishnamurthy, in 1997 [23], showed that melanoma incidence and frequency increase with decreased ozone levels and increased UV light exposure. 


\section{Minimal erythemal dose (MED) and skin phototype}

Careful studies of human skin [24] revealed no significant differences in the actual number of melanocytes. Instead, ethnic differences in skin color come mainly from differences in the rate at which melanosomes are produced and melanized in melanocytes, and then distributed and transferred to neighboring keratinocytes [25].

The concept of "sun reactive" skin typing was created in 1975 for a specific need: to be able to classify persons with "lightly pigmented skin" in order to select the initial correct doses of UVA for the application of the newly developed technique to treat psoriasis using psoralen and UVA [26,27]. A simple classification with only four skin types was initially proposed based on the patient response to an initial sun exposure of 3 MEDs. Later, a complete classification with six skin types was established [27].

In phototesting, a number of skin sites (usually $1 \mathrm{~cm}^{2}$ ) of normal skin are exposed to increasing doses of UVR and are visually examined for erythema $24 \mathrm{~h}$ later [28] to determine the amount or dose of simulated sunlight that they can receive before their skin begins to turn slightly red (Fig. 1). This is called their MED. The MED varies from person to person depending on their skin type. Fairer people tend to go red more quickly

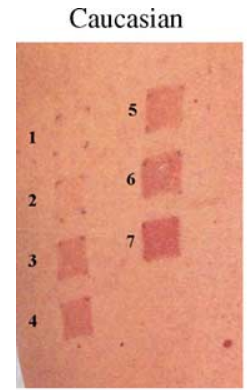

S19

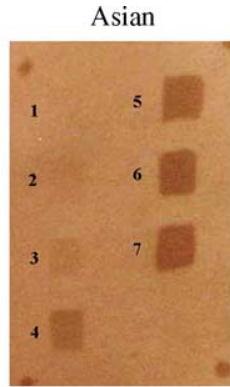

S5

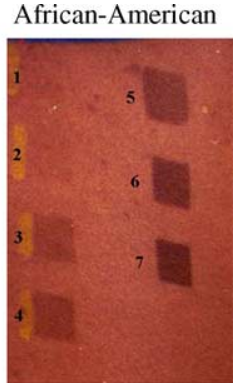

S27
Fig. 1. Skin erythema and pigmentation at day 8 after UVB/UVB irradiation at various doses. Back skin of one subject for each ethnic group studied for MED determination is shown: S19 Caucasian, S5 Asian, S27 African-American. Numbers 1-7 correspond to the following UV doses (in $\mathrm{J} / \mathrm{m}^{2}$ ): $\mathrm{S} 19,1=197,2=380,3=498,4=552$, $5=789,6=1104,7=1577 ; S 5,1=150,2=210,3=300,4=420$, $5=600,6=840,7=1200 ; \mathrm{S} 27,1=406,2=565,3=809,4=1120$, $5=16326=2311,7=3323$. MEDs were determined as $295 \mathrm{~J} / \mathrm{m}^{2}$ for $\mathrm{S} 19,200 \mathrm{~J} / \mathrm{m}^{2}$ for S5 and $765 \mathrm{~J} / \mathrm{m}^{2}$ for $\mathrm{S} 27$. than darker people who have more pigment in their skin. An MED is defined as the lowest exposure that produces a minimally perceptible redness [29]. The assessment of MED is to have an objective determination of the sensitivity of the skin to UV.

The ability to adjust melanization of epidermal cells after sunlight exposure reflects the individual's melanogenic potential, which led to the concept of facultative and constitutive skin color [30]. Constitutive skin color designates a genetically determined level of cutaneous melanin, in the absence of acquired exogenous or endogenous influences. Facultative pigmentation, on the other hand, designates an induced level of increased epidermal melanin content as a result of solar radiation, hormones or other environmental factors. This provides clear separation of two groups of skin phototypes (SPT): sun-sensitive (SPTs I-III who burn and tan with difficulty or not at all) and sun-tolerant (SPTs IV-VI who tan easily and do not burn). In most cases, phototypes show a strong correlation with MEDs [31], except for studies on Korean brown skin [32].

It was recommended that the SPT should be in the medical records of children and adults and that sunsensitive subjects should be told about their SPT and given advice regarding lifelong sun protection to avoid dermatoheliosis and skin cancer [33].

\section{Photoprotective role of melanin}

Melanin serves as a photoprotective agent against the damaging effects of UVR, as evidenced by an inverse correlation between the melanin content of human skin and the incidence of skin carcinomas and melanomas induced by UVR. In the US, rates of basal and squamous cell carcinomas are 50 times higher in Caucasians than in African-Americans [34], who show a 13-fold lower incidence of melanoma [35].

The exact chemical structures of the two types of melanin are still unknown, probably due to complications of copolymerization and numerous postpolymerization modifications [36,37].

The photoprotective properties of melanin in human skin have been well documented [37]. It absorbs both UV and visible light. The absorption increases linearly in the range of $720-620 \mathrm{~nm}$ and then exponentially toward shorter wavelengths $(300-600 \mathrm{~nm})$ [38]. Ultrastructural studies revealed that eumelanosomes that are 
generally produced in dark skin remain intact in the epidermis after UV exposure whereas in fair skin, no intact melanosomes can be detected there $[39,40]$.

\section{The melanocortin receptors}

One way to control skin pigmentation was elucidated at the beginning of the 1990s with the molecular characterization of the melanocyte-stimulating hormone receptor (MSHR) now named melanocortin 1receptor (MC1R) and its antagonist agouti signal protein (ASP) [41,42]. It has been known for many years that two loci, extension and agouti, were involved in the qualitative (eu- and phaeomelanin) and quantitative regulation of mammalian pigmentation $[43,44]$. ASP was known to be produced in hair follicles and to act on follicular melanocytes to inhibit eumelanin synthesis $[45,46]$.

Prior to cloning, two melanocortin receptors, MSHR and the adrenocorticotropic hormone (ACTH) receptor, were known from classical physiological and pharmacological studies. The melanocortin system consists of the melanocortin peptides and various forms of melanocyte-stimulating hormone ( $\alpha-, \beta$ - and $\gamma$-MSH) and $\mathrm{ACTH}$, a family of 5 seven-transmembrane $\mathrm{G}$ protein-coupled melanocortin receptors, and the endogenous melanocortin antagonists ASP and agoutirelated protein. In addition, two ancillary proteins, mahogany and syndecan-3, have been found that modulate the activity of the melanocortin peptides [47]. Those peptides are primarily produced in the pituitary from the cleavage of the pro-opiomelanocortin (POMC) polypeptide. The melanocortins are involved in an extraordinarily diverse number of physiological functions, including pigmentation [48-52], steroidogenesis [53,54], energy homeostasis [55-57], exocrine secretion [58,59], stress [60], sexual function [61,62], analgesia [63], inflammation [64,65], thermoregulation [66], and cardiovascular regulation $[67,68]$. The role of melanocortin peptides in food intake [69-72] and body weight control [73-76] has also been widely investigated.

The MCR pathway includes five known differentially expressed $\mathrm{G}$ protein-coupled receptors: MC1R, corticotropin receptor (ACTHR) also named MC2R, MC3R, MC4R and MC5R [41]. Although all five receptors are known to be Gs-coupled, MC3R has also been shown to function through phospholipase Cmediated hydrolysis of phosphoinositides [77]. MC1R is predominantly expressed in melanocytes, where it is known for its classic role in regulating skin and hair pigmentation in many species. MC1R has also been reported to be expressed in other tissues and cells, such as the pituitary and leukocytes [78], mast cells [79] and pro-monocytes [80], indicating putative physiological roles yet to be unveiled. Several groups have investigated the role of MC1R in inflammation [81-83]. MC3R and MC4R are found in the central nervous system but are notably absent from melanocytes [84]; both are highly expressed in the hypothalamus, where they are involved in energy homeostasis. ACTHR is expressed in the adrenal cortex and MC5R in peripheral cells such as adipocytes [85].

$\alpha \mathrm{MSH}$ is a physiologic agent that controls pigmentation in mammals by inducing melanocyte differentiation and melanin production $[86,87]$. The first step of $\alpha \mathrm{MSH}$ action is its binding to the MC1R on the plasma membrane of the melanocyte $[88,89]$.

\section{Regulation of MC1R activity by its physiological agonists and antagonist}

The significance of human cutaneous pigmentation lies in its protective role against sun-induced DNA damage and photocarcinogenesis $[90,91]$. Total melanin content and the relative amounts of eumelanin and pheomelanin synthesized by human epidermal and follicular melanocytes are important determinants of skin and hair color, respectively [92,93]. Stimulation of MC1R by $\alpha \mathrm{MSH}$ and other POMC peptides induces an increase in intracellular cAMP and the synthesis of photoprotective eumelanin. Phaeomelanin, which may contribute to skin carcinogenesis by producing free radicals in response to UVR [94], is predominantly found in individuals with red hair and fair skin, which may explain the sun sensitivity and the poor tanning ability of these individuals [95].

Injections of human subjects with melanocortins or with an $\alpha$ MSH synthetic analog $[96,97]$ resulted in an increase of cutaneous pigmentation. Treatment of cultured human melanocytes by $\alpha \mathrm{MSH}$ resulted in the increase of melanogenic proteins as well as an increase in cAMP $[92,98,99]$. Disruption of the expression of POMC peptides results in red hair because of the lack 
of eumelanin, as well as adrenal insufficiency and obesity [100].

In mice, as in many other mammals, the wild-type pigmentation pattern of the fur is called agouti. Individual hairs of an agouti coat are black, with a narrow band of pheomelanin in individual hairs. Conversely, in dominant mutations of MC1R, the agouti ring of yellow pigment just below the tip is not found; this alternative synthesis of pheomelanin versus eumelanin is regulated in a paracrine manner by the agouti locus in mice [101]. A short pulse of agouti expression at days 3-5 during the hair-growth cycle [101] leads to a controlled wave of agouti protein secretion from the dermal papillae, which results in a temporary switch to phaeomelanin synthesis $[102,103]$.

Several studies have shown that ASP, the 131 amino acid protein encoded by the agouti gene, acts as a competitive antagonist of the MC1R and blocks its activation by $\alpha \mathrm{MSH}[42,104,105]$. Therefore, the switch between eumelanogenesis and pheomelanogenesis involves the opposing effects of ASP and $\alpha \mathrm{MSH}$ as ligands for that receptor. As previously reported, pheomelanogenesis can be stimulated further by in vitro treatment with purified recombinant ASP [106]. After treatment with ASP, the expression of genes encoding tyrosinase and other melanogenic proteins is suppressed in melanocytes, which also exhibit other physiologic features characteristic of pheomelanogenesis in vivo. In normal human melanocytes (NHM), where the number of MC1R expressed is relatively low [107], ASP completely abrogates the stimulatory effects of $\alpha \mathrm{MSH}$ on melanocyte proliferation and melanogenesis by blocking the binding of $\alpha \mathrm{MSH}$ to the MC1R [99].

\section{Human MC1R allelic variants: link to sun sensitivity and/or melanoma susceptibility}

Human pigmentation is regulated by more than 120 genes [108], and among them, the MC1R is highly polymorphic, suggesting its significance in the wide range of human pigmentation patterns [40]. Today, $M C 1 R$ is the only gene in which variations can explain differences in normal pigmentation in humans [109]. An effect of the MCIR gene on the variation in human pigmentation has been hypothesized since MC1R variants causing coat color changes are known in other mammalian species [110-114]. The MCIR gene has been found to be highly polymorphic in Caucasian populations and specific $M C 1 R$ gene variants such as $\mathrm{R} 142 \mathrm{H}, \mathrm{R} 151 \mathrm{C}, \mathrm{R} 160 \mathrm{~W}$ and D294H have been associated with red hair, fair skin and freckling as well as sun sensitivity in Northern European and Australian populations [115-120]. In addition, recent studies have shown a significant association between the MC1R genotype and both familial and sporadic melanoma [121-123] as well as non-melanoma skin cancer [124].

Fair skin and red hair are also associated with an increased risk of cutaneous malignant melanoma [125]. Increased risks of malignant melanoma have been shown in subjects carrying different $M C 1 R$ gene variant alleles $[121,126,127]$. Carriers of the D84E variant allele were found to have an increased risk of malignant melanoma in a study reported by Valverde and co-workers [126] and by Kennedy et al. [123], but later studies by the same research group [127] and by other research groups $[121,128]$ were not able to confirm this association. More recently, the R151C, R160W and D294H variant alleles were reported to be associated with an increased risk of malignant melanoma [121]. The association between MC1R variants and malignant melanoma suggests that the $M C 1 R$ gene is a susceptibility gene for this type of skin malignancy [122]. The role of $M C 1 R$ gene variants in modulating the risk of non-melanoma skin cancer, however, is largely unknown. In a small group of British patients with non-melanoma skin cancer, an overrepresentation of the D294H variant allele was found [116]. Such an overrepresentation, however, could not be confirmed in a study of patients with basal cell carcinoma [128].

Melanocytes that express the consensus sequence for MC1R have dark pigmentation [129]. More than $30 \mathrm{MC} 1 \mathrm{R}$ variants have been described, of which 9 have been demonstrated to be loss of function variants [130,131]. Some of these variants (V60L, I40T, R142H, R151C, R162P, R160W, and D294H) are unable to stimulate cAMP production as strongly as the wild-type receptor in response to $\alpha \mathrm{MSH}$ stimulation [132-135] whereas others (e.g., V122M) demonstrate a decreased $\alpha \mathrm{MSH}$ binding affinity. Three MC1R variants alleles (R151C, R160W and D294H) have been shown to be associated with the red hair and fair skin (RHC) phenotype [136], a condition that is caused by the predominant level of phaeomelanin synthesis and that can place individuals at higher risks of skin cancer [137]. RHC is characterized by fair pigmen- 
tation (fair skin, red hair and freckles), and by sun sensitivity (poor tanning response and solar lentigines) [116-120,123]. In addition, seven other alleles (V60L, 86insA, D84E, R142H, I155T, 537insC and H260P) may be statistically considered full or partial RHC causing alleles, as shown by genetic associations in populations or through inheritance of phenotype in families [137]. Furthermore, MC1R variants appear to increase the penetrance of p16INK4A mutations in melanoma prone families $[122,138]$.

\section{Response of melanocytes to UVR}

We previously reported that exposure of cultured primary melanocytes to UVR induced a significant reduction in MC1R mRNA level [93]. This effect disappeared within $24 \mathrm{~h}$ after $\mathrm{UV}$ irradiation at relatively low doses, but persisted in NHM irradiated with a cytotoxic dose of UVR. The reversal of the effects of low or moderate doses of UVR might be attributed to stimulation of $\alpha \mathrm{MSH}$ and ACTH production in NHM $[139,140]$, which is expected to up-regulate MC1R expression in a paracrine fashion. We proposed a model for the UVR induced melanogenesis in NHM. UVR affects NHM directly by damaging the DNA, as well as indirectly by stimulating the synthesis of a variety of epidermal factors, such as $\alpha \mathrm{MSH}, \mathrm{ACTH}, \mathrm{bFGF}$ and ET-1 [139-144]. Many of those factors act as paracrine regulators that mediate the effects of UVR on melanogenesis, proliferation, as well as survival of melanocytes. Although these factors activate different signaling pathways, they converge on the up-regulation of MC1R mRNA level, suggesting a central role of MC1R in determining human cutaneous pigmentation. Increasing the level of MC1R mRNA is expected to enhance the response of melanocytes to $\alpha \mathrm{MSH}$ and ACTH and to mediate the pigmentary response to UVR, as proposed previously in studies using mouse melanoma cells [145-147].

Binding of $\alpha \mathrm{MSH}$ and $\mathrm{ACTH}$ to MC1R stimulates the synthesis of cAMP (Fig. 2), activates cAMPdependent protein kinase $\mathrm{A}$, and subsequently a series of downstream targets, many of which are yet to be identified $[99,147]$. This cascade of events leads to the stimulation of proliferation and melanogenesis of NHM [98]. The MC1R functions as a primary regulator of eumelanin synthesis in mammalian
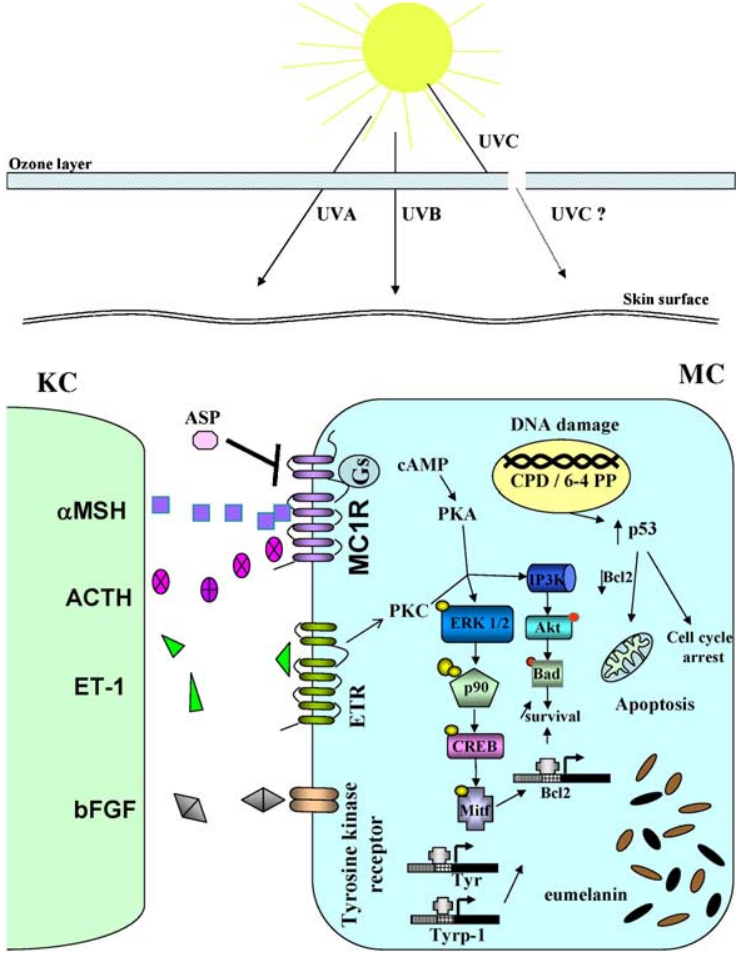

Fig. 2. Summary of the effects of UV in human skin melanocytes and keratinocytes. Exposure of human skin to UV results in the release of a variety of factors by keratinocytes, among which ACTH and MSH will bind to the MC1R and activate the cAMP/ PKA pathway. Formation of DNA photoproducts will lead to an activation of the p53 pathway, resulting in apoptosis, G1 arrest and DNA repair. Few hours after UV exposure, accumulation of $\mathrm{p} 53$ in response to DNA damage and reduction in Bcl2 level are observed. UV activates Akt, which in turn phosphorylates and inhibits the apoptotic effect of Bad. Upon UVR stimulation, activated CREB is expected to activate Mitf that increases melanogenesis and promotes the survival of melanocytes.

melanocytes. This has been demonstrated in mouse follicular melanocytes decades ago, and more recently in human epidermal melanocytes [93,148,149].

$\mathrm{G}$ protein-coupled receptors owe their name to their extensively studied interaction with heterotrimeric $G$ proteins (composed of an $\alpha$-, $\beta$ - and $\gamma$-subunit), which undergo conformational changes that lead to the exchange of GDP for GTP bound to the $\alpha$-subunit following receptor activation [150]. Consequently, the $\mathrm{G}$ subunits stimulate effector molecules, which include adenylyl and guanylyl cyclases, phosphodiesterases, phospholipase A2, phospholipase C and phosphoinositide 3-kinases, thereby activating or in- 
hibiting the production of a variety of second messengers such as cAMP, cGMP, diacylglycerol, inositol (1,4,5)-trisphosphate (IP3), phosphatidyl inositol (3,4,5)-trisphosphate (PIP3), arachidonic acid and phosphatidic acid, in addition to increasing the intracellular concentration of calcium and opening or closing a variety of ion channels.

When the MC1R is activated upon ligand binding, the G-protein activates adenylyl cyclase resulting in a significant increase of intracellular cAMP. In cultured human melanocytes and in mouse melanoma cells, $\alpha \mathrm{MSH}$ and ACTH up-regulate melanogenesis and dendricity $[98,151]$. These effects can be mimicked by pharmacological cAMP elevating agents such as forskolin, cholera toxin or isobutylmethylxanthine [152].

\section{Response of MC1R to UV/ $\alpha \mathrm{MSH}$ with respect to the various genotypes/phenotypes}

More than 30 allelic variants of the human MC1R have been identified, mainly in Northern European populations and in Australia [115,116,120,153]. As noted above, among the variants so far reported, R142H, R151C, R160W and D294H are the mutations mostly associated with red hair phenotype and reduced tanning ability $[116,118,120,154]$. These four MC1R variants are common in melanoma patients, and increase the risk of melanoma by more than two-fold [121]. Homozygote or compound heterozygote variant MC1R genotype carriers are generally red-haired, however, the existence of exceptions indicate that other loci are involved in the phenotype expression [120]. Red hair occurs in a significant proportion of compound heterozygote variants, and some alleles are shown to be stronger (D84E, R151C, R160W and D294H) than others (V60L, V92M and R63Q) in determining the phenotype [154].

The consequences of these variants on physiological function of the MC1R have just begun to be uncovered. It is known that R160W homozygote and R151C/D294H, R160W/D294H compound heterozygote NHM, fail to couple to cAMP activation, show impaired tyrosinase activation in response to $\alpha \mathrm{MSH}$ stimulation and display a pronounced sensitivity to UVR [93]. Similar failures in activating cAMP formation were also demonstrated in heterologous expres- sion systems [132,133]. The significance of the MC1R in cutaneous responses to UVR is emphasized by the exaggerated sensitivity to UVR of melanocytes with loss-of-function MC1R compared to melanocytes with functional MC1R and comparable levels of melanin [93].

Exposure of NHM to UV results in the immediate formation of hydrogen peroxide and a dosedependent generation of DNA photoproducts, which lead to the arrest of melanocytes in the G1 phase of the cell cycle and then to apoptosis. Treatment of melanocytes with melanocortins or ET-1 partially rescues them from the UV-induced G1 arrest [155]. The levels of cyclobutane dimers formed immediately following UVB was similar in melanocytes homozygous for R160W mutation in MC1R and in melanocytes with comparable melanin content and functional MC1R. The increased apoptosis observed in melanocytes with loss of function MC1R is due to the accumulation of DNA lesions and inefficient repair of UV-induced DNA damage. $\alpha \mathrm{MSH}$ and ET-1 inhibit the apoptosis of melanocytes following UV exposure. Importantly, $\alpha \mathrm{MSH}$ enhances the survival of melanocytes carrying functional MC1R, but not melanocytes expressing lossof-function mutations in the MCIR gene (unpublished data). Comparison of functional and non-functional MC1R melanocytes suggests that a functional MC1R is necessary to cope with the DNA damage induced by UVR.

\section{Indirect effects}

Interestingly, UV has been shown to increase POMC production by keratinocytes [156]. It should be mentioned that in human epidermis the major POMC peptide seems to be ACTH [144], which is actually more efficient at activating MC1R than are the various forms of $\alpha \mathrm{MSH}$. Additionally, studies on murine melanoma cells have demonstrated that UVB radiation up-regulates the expression of MC1R [157]. Very recently, it has been shown that UV down-regulates the expression of neprilysine, a peptidase that cleaves and inactivates $\alpha \mathrm{MSH}$ and ACTH [158]. Thus, UVR can modulate POMC action in the epidermis in three different ways that converge to reinforce their melanogenic functions. Effects of cAMP on melanocytes have been recently reviewed [159]. Melanocytes cultivated in 
keratinocyte-conditioned media respond by increasing their growth, melanogenesis and dendricity [160]. These effects are enhanced by keratinocytes exposed to UVR, strongly suggesting that keratinocytes secrete specific factors responsible for melanocyte activation. Therefore, keratinocytes seem to be a key cellular component in the physiological tanning response [161]. Keratinocyte-secreted factors, which induce melanocyte activation, include prostaglandin PGE2 [162], $\alpha \mathrm{MSH}$ and ACTH [156,163], endothelin$1[164,165]$ and NO [160]. $\alpha \mathrm{MSH}, \mathrm{ACTH}$ and PGE2 activate the cAMP pathway in melanocytes, while NO activates the cGMP-dependent signaling events.

\section{Melanocyte survival}

In vitro, melanocytes respond to UV with dosedependent growth arrest and reduction in survival $[143,155,166]$. Melanocytes have low proliferation capacity and it is reasonable to assume that due to their significance in photoprotection of the skin, mechanisms were selected insuring melanocyte survival. In fact, melanocytes are thought to resist apoptosis by constitutive expression of the anti-apoptotic protein $\mathrm{Bcl} 2$.

Many of the effects of UV on human skin are indirectly mediated by up-regulating the synthesis of various growth factors and cytokines, some of which function as paracrine or autocrine regulators of melanocytes [140,167]. Among those factors are $\alpha \mathrm{MSH}$ and endothelin-1 (ET-1), synthesized by various epidermal cell types. $\alpha \mathrm{MSH}$ and ET-1 are mitogenic and melanogenic to human melanocytes, and both are important participants in the melanogenic response of melanocytes to UV $[155,166,168]$. Recently, new roles for $\alpha \mathrm{MSH}$ and ET-1 as pro-survival agents were described for UV-irradiated melanocytes. The survival effects of $\alpha \mathrm{MSH}$ and ET-1 were shown to be independent of their melanogenic or mitogenic effects and to involve the activation of a critical survival pathway involving IP3 kinase and its substrate Akt/PKB [40].

The IP3 kinase pathway is an important survival pathway in many types of cells, such as neurons, fibroblasts and keratinocytes, and mediates the effects of various survival factors, such as insulin-like growth factor, nerve growth factor, platelet-derived growth factor, mast cell growth factor, epidermal growth factor and hepatocyte growth factor [169-174]. Activation of IP3 kinase results in increased levels of PIP3 and inositol 3,4-biphosphate, which ultimately lead to the activation of the serine-threonine kinase Akt/PKB. Activated Akt inhibits apoptosis, particularly the intrinsic apoptotic pathway, by phosphorylating and inactivating the pro-apoptotic proteins Bad and caspase 9, and additionally, Akt phosphorylates IкB, resulting in the activation of NFKB that inhibits apoptosis [175].

The cAMP dependent pathway, the main signaling pathway activated by $\alpha \mathrm{MSH}$ through the MC1R, also stimulates Akt/PKB activity in an IP3K-independent mechanism [176]. Activation of the MAP kinases ERK1/2, and subsequently the transcription factor CREB, results in the phosphorylation and activation of Mitf in melanocytes, as demonstrated in melanocytes treated with stem cell factor, the c-kit ligand [177]. Treatment of human melanocytes with ET-1 activates the same MAP kinase pathway and phosphorylates CREB on serine 133; these effects are enhanced in the concomitant presence of $\alpha \mathrm{MSH}[178,147]$. Irradiation of human melanocytes with UV leads to the phosphorylation, and hence the activation, of Mitf which is downstream from CREB. ET-1 or $\alpha \mathrm{MSH}$ also stimulate the phosphorylation of Mitf, and this effect might be regulated indirectly by Akt. While UV inhibits the level of Bcl2, treatment with ET-1 or $\alpha \mathrm{MSH}$ markedly abrogated this effect.

Since UV-induced apoptosis occurs in cells with extensive DNA damage, it is plausible that the antiapoptotic effect of $\alpha \mathrm{MSH}$ is due to enhanced DNA repair, which would reduce UV induced mutagenesis and carcinogenesis.

\section{UV-induced DNA damage}

The most drastic effects of UV exposure are photoaging and photocarcinogenesis. Melanin guards against the photodamaging effects of UV by acting as a filter that limits the penetration of UV rays through the epidermis [90,91]. Melanin also acts as a scavenger of UV-induced reactive oxygen species that cause lipid peroxidation and damage proteins and DNA [179]. Acute exposure of the skin to solar UV results in ex- 
tensive DNA damage, leading to apoptosis, which is best evidenced by the appearance of sunburn cells, i.e., apoptotic keratinocytes, in the epidermis [180]. UVB is the most cytotoxic and mutagenic waveband of solar radiation. UVB irradiation of mammalian cells produces damage at the level of proteins, lipids and DNA, according to the wavelengths that reach the cells. Many of the deleterious effects of UVB will occur in the DNA, since DNA bases directly absorb incident photons within this narrow wavelength range. UVB and UVC irradiation can generate pyrimidine dimer photoproducts, particularly cyclobutane pyrimidine dimers (CPD) and 6,4-photoproducts (64PP) (Fig. 3), at a ra- tio that varies from 4:1 to $10: 1[181,182]$. The presence of these DNA lesions can potentially induce mutations and eventually lead to the development of skin cancer. The phototoxic effect of UVA radiation is much lower than UVB, since DNA is not a chromophore for the long UVA wavelengths [183]. However, UVA can produce DNA damage indirectly through the generation of oxidative stress.

Electron transfer or singlet molecular oxygen produced by UVB and UVA radiation targets the DNA base guanine, giving rise to 8-hydroxydeoxyguanosine (8-OHdG) in the DNA strand [184]. 8-OHdG is a miscoding lesion caused by $\mathrm{G}$ to $\mathrm{T}$ transversion that is
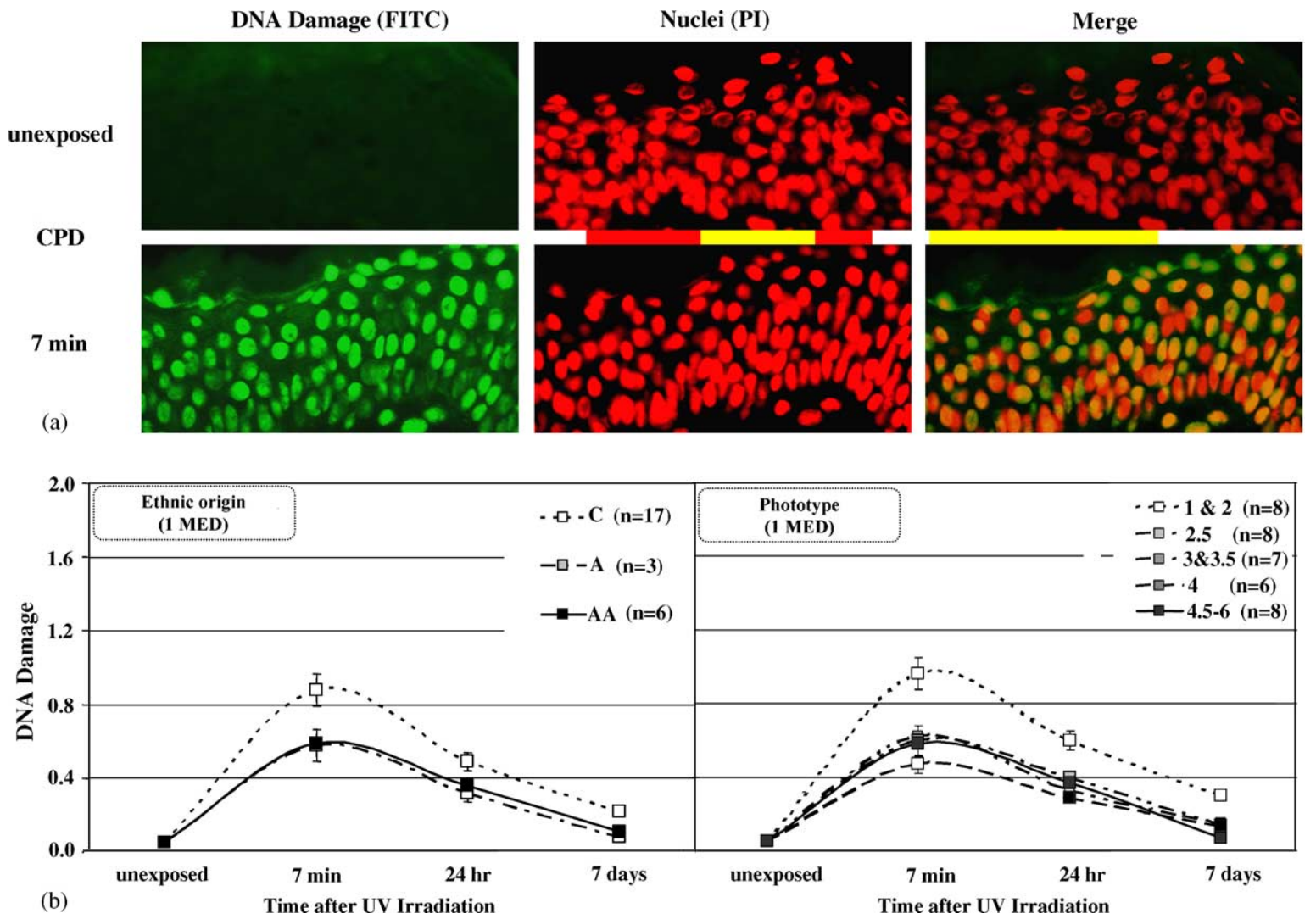

Fig. 3. (a) Immunohistochemical detection of CPD DNA photoproducts. DNA damage detected by FITC (green, left column) and nuclei detected by PI (red, central column) in UV-irradiated skin. Typical fluorescence image from one subject (S26, a Caucasian male, SPT 4.5) is shown. The right column shows the merged images, and colocalization of DNA over the nuclei is seen as the yellow color. Row 1 shows skin before UV irradiation and row 2 shows skin 7 min after UV exposure. Modified from Tadokoro et al., UV-induced DNA damage and melanin content in human skin differing in racial/ethnic origin. Taken from ref. [182]. (b) Effects of different skin characteristics on DNA damage. DNA damage (as CPD) was measured before 1 MED UV irradiation and various times thereafter. The data are grouped by ethnic origin (C: Caucasian, A: Asian, AA: African-American) and by SPT. Results are reported as means of each group and the error bars reflect the SE. UV-induced DNA damage and melanin content in human skin differing in racial/ethnic origin. Adapted in part from ref. [182]. 
known to be a ubiquitous marker of oxidative stress, since it can be generated under various agents such as peroxynitrite, $\mathrm{OH}$ radical and singlet oxygen [185]. Recently, it was demonstrated that UVA also induces DNA photoproducts [186].

UV-induced CPD and 64PP generate abnormalities in DNA structure that can be recognized and corrected by the highly conserved nucleotide excision repair (NER) system [187]. These bulky DNA lesions inhibit RNA polymerase II giving rise to a signal that results in a preferential repair of lesions located on transcribed strands. During the course of repair a 26-30 base oligonucleotide containing the lesion, the gap is filled by unscheduled DNA synthesis carried out by DNA polymerase in the presence of PCNA and various replication factors. This transcription-coupled repair is vital for cell survival after UV exposure. Its impairment gives rise to serious DNA repair deficiencies that are well documented by the high incidence of skin cancer on sun-exposed areas in xeroderma pigmentosum patients [188].

Base changes, such as $8-\mathrm{OHdG}$, that represent only a minor fraction of UV-induced mutations [185] are repaired by the base excision repair system [187]. NER is the main mechanism for repairing UVB-induced DNA damage in mammalian cells. Recently, the immunomodulatory mediator IL-12 has been shown to protect cells from apoptosis induced by DNA damaging UVB radiation, through the enhancement of NER activity [189]. A similar finding was demonstrated by the hepatocyte growth factor/scatter factor enhancing the repair of DNA strand breaks in cell lines carrying p53 mutations [190]. These are very significant findings since they uncover the possible role of cytokines in modulation of NER.

The observation that melanocytes with high eumelanin to pheomelanin ratios and loss-of-function MC1R, are more sensitive to UVR-induced cytotoxicity than are wild-type melanocytes regardless of constitutive pigmentation [93], suggests that the inability of melanocytes to respond to $\alpha \mathrm{MSH}$ reduces their defense mechanisms against UVR genotoxicity. Preliminary results comparing functional and non-functional MC1R melanocytes show that the non-functional MC1R cells have a very slow rate of CPD removal, suggesting the importance of $\mathrm{MC} 1 \mathrm{R} / \alpha \mathrm{MSH}$ in DNA repair (unpublished results).

\section{UVR induces local and systemic immunosuppression}

UVB radiation is among the most ubiquitous agents in the environment, and humans are invariably exposed to it. UVR not only initiates and promotes the transformation of normal epidermal cells to cancer cells via dysregulation of intracellular signaling pathways and via its mutagenic effects on cellular DNA, but also by altering the host immunity by reducing its capability for surveillance against tumor or viral antigens. Since UVB radiation is almost completely absorbed within the epidermis, epidermal cells are considered to be the targets for UV effects. Dendritic Langerhans cells reside in the suprabasal layer of the epidermis and they play an essential role in immune responses initiated in the skin. Their function is to pick up antigens or haptens within the epidermal layer and then to migrate to draining lymph nodes where antigen presentation to specific T cells occurs [191]. In vitro exposure to a narrow band of UVB radiation $(312 \mathrm{~nm})$ induces a potent inhibition of human Langerhans cells antigen presenting function [192]. Both local and systemic UVB-induced immunosuppression have been related to deleterious effects of this radiation on epidermal cells. Based on studies performed mainly in the murine system, immunosuppression has been shown to result both from direct effects of UVB radiation on Langerhans cells antigen-presenting function [193] and from indirect effects mediated through keratinocyte-derived suppressive factors [194].

Elmets et al. [195] demonstrated in the early 1980s that low doses of UVB radiation to the skin inhibited its response to haptens painted on irradiated sites, although haptens painted on unirradiated skin induced a strong contact hypersensitivity (CHS). Yoshikawa et al. [196] showed that most skin cancer patients exposed to UVB failed to develop CHS to haptens, whereas about $60 \%$ of healthy subjects developed vigorous CHS. These subjects who failed to induce an immune reaction were called UV-susceptible and the others were called UV-resistant. It was postulated that UV-susceptibility might be a risk factor for the development of skin cancer. Fisher and Kripke [197] reported that skin tumors that developed in adult mice exposed to high doses of UVB radiation for prolonged periods of time were rejected when transplanted to syngeneic healthy mice, but continued to grow 
when transplanted to mouse skin pre-exposed to UVB radiation.

UVR induces keratinocytes to release IL-10, which alters antigen presenting cell function by preferentially activating Th2 suppressor cells. Th2 cells mediate their suppressive effects by releasing cytokines such as IL-4 and IL-10 [198,199]. The effects of IL10 on the immune response are counteracted by IL12 , which blocks the suppression of delayed-type hypersensitivity reactions observed in UV-induced suppressor T cells, has the ability to stimulate Th1 cells [197] and blocks the differentiation of Th2 cells [200].

\section{Anti-inflammatory effect of $\alpha \mathrm{MSH}$, role of MC1R?}

$\alpha \mathrm{MSH}$ is one mediator capable of counteracting inflammation. MC1R, first demonstrated in melanoma tumor cell lines [201], is present on immunologically important cells such as macrophages, monocytes, dendritic cells and neutrophils [202-205].

MC1R expression has been shown to be upregulated not only in melanocytes, but also in monocytes in response to external stimuli such as UVBradiation and retinoic acid [206]. Support for the antiinflammatory effects of $\alpha \mathrm{MSH}$ is found in studies using a mouse model of CHS and the induction of haptenspecific tolerance in mice [206]. The immunomodulatory action of $\alpha \mathrm{MSH}$ includes both immunostimulatory and immunosuppressive effects [207]. Several studies have shown that $\alpha \mathrm{MSH}$ antagonizes the effects of proinflammatory cytokines such as IL- $1 \alpha$, IL- $1 \beta$, IL- 6 and tumor necrosis factor- $\alpha$, and induces the production of anti-inflammatory cytokines [208,209].

Besides its presence in the skin and in circulating blood, $\alpha \mathrm{MSH}$ is widely distributed in various regions in the brain. Inflammation, known as a localized response to tissue injury, can also be observed in neurological disorders that are associated with infectious agents as well as in other disorders such as multiple sclerosis, Alzheimer's disease, stroke and neurodegenerative disorders. $\alpha \mathrm{MSH}$ is also known to modulate CNS inflammation. It was shown that the neuropeptide inhibits the production of tumor necrosis factor- $\alpha$ in murine brain [210]. The mechanism by which $\alpha \mathrm{MSH}$ induces the anti-inflammatory effects is not completely understood, but it seems that the induced effect is extremely rapid.

\section{Concluding remarks}

Cancer of the skin is the most common of all cancers. Melanoma accounts for about $4 \%$ of skin cancer cases, but it causes about $79 \%$ of skin cancer deaths. The number of new cases of melanoma in the United States is on the rise. The American Cancer Society estimates that in 2004 there will be 64,200 new cases of melanoma in this country and that about 8600 people will die of this disease. Australia, Northern European and other countries are also paying a huge price to skin cancer. There is an urgency to bring together an appropriate scientific task force to fight against what tomorrow could be a tremendous public health tragedy. We focus our efforts on characterizing the regulation of mammalian pigmentation, with the ultimate goal of optimizing skin pigmentation and photoprotection, and in developing novel approaches for targeting malignant melanoma. The importance of skin pigmentation, particularly with respect to photoprotection against skin cancers (including malignant melanoma), has underscored the importance of such research. The alarming increase in incidence of all types of skin cancers in recent decades has also been a major stimulus.

In this paper, we have reviewed advances of the role of the MC1R and the responses of melanocytes to UVR. $\mathrm{MC} 1 \mathrm{R}$ functions as a primary regulator of eumelanin synthesis in human melanocytes, and therefore is the key control point of melanocyte responses to UVR. Given the significance of the MC1R in determining the risk for skin cancer, particularly melanoma, preventative strategies should be developed based on activating the receptor by potent melanocortin agonists. This would be of particular benefit to individuals that are heterozygous for one allelic variant of MC1R, with a reduced response to endogenous melanocortins and with a high risk for melanoma.

\section{References}

[1] C. Jhappan, F.P. Noonan, G. Merlino, Ultraviolet radiation and cutaneous malignant melanoma, Oncogene 22 (2003) 3099-3112. 
[2] F.W. Herschel, Investigation of the powers of the prismatic colours to heat and illuminate objects, Philos. Trans. R. Soc. Lond. P. II (1800) 255-292.

[3] J.W. Ritter. Bemerkungen zu Herschel's neueren Untersuchungen uber das Licht; vorgelesen in der Naturforschenden Gesellschaft zu Jena, im Fruhling 1801. Phys. Chem. Abh. vol. 2, Leipzig, 1801.

[4] N. Morley, A. Curnow, L. Salter, S. Campbell, D. Gould, $N$ Acetyl-L-cysteine prevents DNA damage induced by UVA, UVB and visible radiation in human fibroblasts, J. Photochem. Photobiol. B 72 (2003) 55-60.

[5] D.E. Heck, D.R. Gerecke, A.M. Vetrano, J.D. Laskin, Solar ultraviolet radiation as a trigger of cell signal transduction, Toxicol. Appl. Pharmacol. 195 (2004) 288-297.

[6] A. Mahns, R. Wolber, F. Stab, L.O. Klotz, H. Sies, Contribution of UVB and UVA to UV-dependent stimulation of cyclooxygenase-2 expression in artificial epidermis, Photochem. Photobiol. Sci. 3 (2004) 257-262.

[7] B.L. Diffey, Sources and measurement of ultraviolet radiation, Methods 28 (2002) 4-13.

[8] C. Huang, W. Ma, Z. Dong, Signal transduction through atypical PKCs, but not the EGF receptor, is necessary for UVCinduced AP-1 activation in immortal murine cells, Oncogene 14 (1997) 1945-1954.

[9] S.A. Miller, S.L. Hamilton, U.G. Wester, W.H. Cyr, An analysis of UVA emissions from sunlamps and the potential importance for melanoma, Photochem. Photobiol. 68 (1998) 6370.

[10] D.G. Pitts, Sunlight as an ultraviolet source, Optom. Vis. Sci. 67 (1990) 401-406.

[11] B.L. Diffey, What is light? Photodermatol. Photoimmunol. Photomed. 18 (2002) 68-74.

[12] G.D. Hayman, CFCS and the ozone layer, Br. J. Clin. Pract. Suppl. 89 (1997) 2-9.

[13] M.J. Molina, F.S. Rowland, Stratospheric sink for chlorofluoromethanes-chlorine atomic-catalyzed destruction of ozone, Nature 249 (1974) 810-812.

[14] A. Reizian-Fouley, Y. Dat, S. Rault, Chlorofluorocarbon CFCs, potential alternative HCFCs and HFCs, and related chlorinated compounds: mass spectral study Part II, Ecotoxicol. Environ. Saf. 36 (1997) 197-204.

[15] World Meteorological Organization Global Ozone Research and Monitoring Project, Scientific Assessment of Ozone Depletion: 1998, Report No. 44, Geneva, 1999.

[16] P. Musk, R. Campbell, J. Staples, D.J. Moss, P.G. Parsons, Solar and UVC-induced mutation in human cells and inhibition by deoxynucleosides, Mutat. Res. 227 (1989) 25-30.

[17] N.J. Mork, H. Borufsen, L.R. Braathen, UVC irradiation of human epidermal langerhans cells decreases the alloactivating and antigen presenting capacity, Clin. Exp. Dermatol. 13 (1988) 371-375.

[18] Y.C. Chen, S.Y. Lin-Shiau, J.K. Lin, Involvement of heatshock protein 70 and P53 proteins in attenuation of UVCinduced apoptosis by thermal stress in hepatocellular carcinoma cells, Photochem. Photobiol. 70 (1999) 78-86.

[19] A. Rasouli-Nia, F. Karimi-Busheri, M. Weinfeld, Stable downregulation of human polynucleotide kinase enhances sponta- neous mutation frequency and sensitizes cells to genotoxic agents, Proc. Natl. Acad. Sci. U.S.A. 101 (2004) 6905-6910.

[20] Z. Liu, M. Hergenhahn, H.H. Schmeiser, G.N. Wogan, A. Hong, M. Hollstein, Human tumor p53 mutations are selected for in mouse embryonic fibroblasts harboring a humanized p53 gene, Proc. Natl. Acad. Sci. U.S.A. 101 (2004) 29632968.

[21] K.K. Newsham, UV-B radiation arising from stratospheric ozone depletion influences the pigmentation of the Antarctic moss Andreaea regularis, Oecologia 135 (2003) 327-331.

[22] A. Kolstad, Risk perception related to depletion of the ozone layer and UV-B radiation in the arctic, Int. J. Circumpolar. Health 57 (Suppl. 1) (1998) 596-600.

[23] S. Krishnamurthy, The geography of non-ocular malignant melanoma in India: its association with latitude, ozone levels and UV light exposure, Int. J. Cancer 51 (1992) 169-172.

[24] G. Szabo, A.B. Gerald, M.A. Pathak, T.B. Fitzpatrick, Racial differences in the fate of melanosomes in human epidermis, Nature 222 (198) (1969) 1081-1082.

[25] T.B. Fitzpatrick, Mammalian melanin biosynthesis, Trans. St. Johns Hosp. Dermatol. Soc. 51 (1965) 1-26.

[26] J.A. Parrish, T.B. Fitzpatrick, L. Tanenbaum, M.A. Pathak, Photochemotherapy of psoriasis with oral methoxsalen and longwave ultraviolet light, N. Engl. J. Med. 291 (1974) 1207-1211.

[27] T.B. Fitzpatrick, The validity and practicality of sun-reactive skin types I through VI, Arch. Dermatol. 124 (1988) 869-871.

[28] N. Kollias, A. Baqer, I. Sadiq, Minimum erythema dose determination in individuals of skin type $\mathrm{V}$ and VI with diffuse reflectance spectroscopy, Photodermatol. Photoimmunol. Photomed. 10 (1994) 249-254.

[29] P.P. Agin, D.L. Desrochers, R.M. Sayre, The relationship of immediate pigment darkening to minimal erythemal dose, skin type, and eye color, Photodermatol. 2 (1985) 288-294.

[30] M.A. Pathak, Activation of the melanocyte system by ultraviolet radiation and cell transformation, Ann. N. Y. Acad. Sci. 453 (1985) 328-339.

[31] S. Astner, R.R. Anderson, Skin phototypes, J. Invest. Dermatol. 122 (2004).

[32] J.I. Youn, J.K. Oh, B.K. Kim, D.H. Suh, J.H. Chung, S.J. Oh, J.J. Kim, S.H. Kang, Relationship between skin phototype and MED in Korean, brown skin, Photodermatol. Photoimmunol. Photomed. 13 (1997) 208-211.

[33] T.B. Fitzpatrick, Skin phototypes, in: 20th World Congress of Dermatology, Paris, July 1-5, 2002 (Poster \#1788).

[34] R.M. Halder, S. Bridgeman-Shah, Skin cancer in African-Americans, Cancer 75 (1995) 667-673.

[35] T. Tadokoro, N. Kobayashi, J.Z. Beer, B.Z. Zmudska, K. Wakamatsu, S.A. Miller, M.L. Lamoreux, S. Ito, V.J. Hearing, The biochemistry of melanogenesis and its regulation by ultraviolet radiation, in: Mechanisms of Suntanning, Martin Dunitz Ltd., 2001.

[36] S. Ito, Reexamination of the structure of eumelanin, Biochim. Biophys. Acta 883 (1986) 155-161.

[37] N. Kollias, R.M. Sayre, L. Zeise, M.R. Chedekel, Photoprotection by melanin, J. Photochem. Photobiol. B 9 (1991) $135-160$. 
[38] H. Ou-Yang, G. Stamatas, N. Kollias, Spectral responses of melanin to ultraviolet A irradiation, J. Invest. Dermatol. 122 (2004) 492-496.

[39] M.A. Pathak, Y. Hori, G. Szabo, T.B. Fitzpatrick, The photobiology of melanin pigmentation in human skin, in: T. Kawamura, T.B. Fitzpatrick (Eds.), Biology of Normal and Abnormal Melanocytes, University of Tokyo Press, Tokyo, 1971, pp. 149-169.

[40] A.L. Kadekaro, H. Kanto, R. Kavanagh, Z.A. Abdel-Malek, Significance of the melanocortin 1 receptor in regulating human melanocyte pigmentation, proliferation, and survival, Ann. N. Y. Acad. Sci. 994 (2003) 359-365.

[41] K.G. Mountjoy, L.S. Robbins, M.T. Mortrud, R.D. Cone, The cloning of a family of genes that encode the melanocortin receptors, Science 257 (1992) 1248-1251.

[42] D. Lu, D. Willard, I.R. Patel, S. Kadwell, L. Overton, T. Kost, M. Luther, W. Chen, R.P. Woychik, W.O. Wilkison, R.D. Cone, Agouti protein is an antagonist of the melanocytestimulating-hormone receptor, Nature 371 (6500) (1994) 799-802.

[43] C.C. Little, The Inheritance of Coat Color in Dogs, Howell, New York, 1957.

[44] A.G. Searle, Comparative Genetics of Coat Colour in Mammals, Academic Press, New York, 1968.

[45] W.K. Silvers, The Coat Colors of Mice: A Model for Mammalian Gene Action and Interaction, Springer-Verlag, Basel, Switzerland, 1979.

[46] W.K. Silvers, E.S. Russel, An experimental approach to action of genes at the agouti locus in mouse, J. Exp. Zool. 130 (1955) 199-220.

[47] I. Gantz, T.M. Fong, The melanocortin system, Am. J. Physiol. Endocrinol. Metab. 284 (2003) E468-E474.

[48] F. Rouzaud, J.P. Annereau, J.C. Valencia, G.E. Costin, V.J. Hearing, Regulation of melanocortin 1 receptor expression at the mRNA and protein levels by its natural agonist and antagonist, FASEB J. 17 (2003) 2154-2156.

[49] L. Naysmith, K. Waterston, T. Ha, N. Flanagan, Y. Bisset, A. Ray, K. Wakamatsu, S. Ito, J.L. Rees, Quantitative measures of the effect of the melanocortin 1 receptor on human pigmentary status, J. Invest. Dermatol. 122 (2004) 423-428.

[50] J.L. Rees, Genetics of hair and skin color, Annu. Rev. Genet. 37 (2003) 67-90.

[51] R.A. King, R.K. Willaert, R.M. Schmidt, J. Pietsch, S. Savage, M.J. Brott, J.P. Fryer, C.G. Summers, W.S. Oetting, MC1R mutations modify the classic phenotype of oculocutaneous albinism type 2 (OCA2), Am. J. Hum. Genet. 73 (2003) 638-645.

[52] J. Voisey, N.F. Box, A. van Daal, A polymorphism study of the human Agouti gene and its association with MC1R, Pigment Cell Res. 14 (2001) 264-267.

[53] P.J. O'Shaughnessy, L.M. Fleming, G. Jackson, U. Hochgeschwender, P. Reed, P.J. Baker, Adrenocorticotropic hormone directly stimulates testosterone production by the fetal and neonatal mouse testis, Endocrinology 144 (2003) 3279-3284

[54] L.J. Edwards, A.E. Bryce, C.L. Coulter, I.C. McMillen, Maternal undernutrition throughout pregnancy increases adrenocor- ticotrophin receptor and steroidogenic acute regulatory protein gene expression in the adrenal gland of twin fetal sheep during late gestation, Mol. Cell. Endocrinol. 196 (2002) 1-10.

[55] C.R. Barb, A.S. Robertson, J.B. Barrett, R.R. Kraeling, K.L. Houseknecht, The role of melanocortin-3 and -4 receptor in regulating appetite, energy homeostasis and neuroendocrine function in the pig, J. Endocrinol. 181 (2004) 39-52.

[56] D. Cepoi, T. Phillips, M. Cismowski, V.S. Goodfellow, N. Ling, R.D. Cone, W. Fan, Assessment of a small molecule melanocortin-4 receptor-specific agonist on energy homeostasis, Brain Res. 1000 (2004) 64-71.

[57] K.L. Ellacott, R.D. Cone, The central melanocortin system and the integration of short- and long-term regulators of energy homeostasis, Recent Prog. Horm. Res. 59 (2004) 395-408.

[58] W. Chen, M.A. Kelly, X. Opitz-Araya, R.E. Thomas, M.J. Low, R.D. Cone, Exocrine gland dysfunction in MC5-Rdeficient mice: evidence for coordinated regulation of exocrine gland function by melanocortin peptides, Cell 91 (1997) 789-798.

[59] M. van der Kraan, R.A. Adan, M.L. Entwistle, W.H. Gispen, J.P. Burbach, J.B. Tatro, Expression of melanocortin-5 receptor in secretory epithelia supports a functional role in exocrine and endocrine glands, Endocrinology 139 (1998) 2348-2355.

[60] S. Chaki, S. Ogawa, Y. Toda, T. Funakoshi, S. Okuyama, Involvement of the melanocortin MC4 receptor in stress-related behavior in rodents, Eur. J. Pharmacol. 474 (2003) 95-101.

[61] L.H. Van der Ploeg, W.J. Martin, A.D. Howard, R.P. Nargund, C.P. Austin, X. Guan, J. Drisko, D. Cashen, I. Sebhat, A.A. Patchett, D.J. Figueroa, A.G. DiLella, B.M. Connolly, D.H. Weinberg, C.P. Tan, O.C. Palyha, S.S. Pong, T. MacNeil, C. Rosenblum, A. Vongs, R. Tang, H. Yu, A.W. Sailer, T.M. Fong, C. Huang, M.R. Tota, R.S. Chang, R. Stearns, C. Tamvakopoulos, G. Christ, D.L. Drazen, B.D. Spar, R.J. Nelson, D.E. MacIntyre, A role for the melanocortin 4 receptor in sexual function, Proc. Natl. Acad. Sci. U.S.A. 99 (2002) 11381-11386.

[62] P.B. Molinoff, M.A. Shadiack, D. Earle, L.E. Diamond, C.Y. Quon, PT-141: a melanocortin agonist for the treatment of sexual dysfunction, Ann. N. Y. Acad. Sci. 994 (2003) 96-102.

[63] J.S. Mogil, S.G. Wilson, E.J. Chesler, A.L. Rankin, K.V. Nemmani, W.R. Lariviere, M.K. Groce, M.R. Wallace, L. Kaplan, R. Staud, T.J. Ness, T.L. Glover, M. Stankova, A. Mayorov, V.J. Hruby, J.E. Grisel, R.B. Fillingim, The melanocortin-1 receptor gene mediates female-specific mechanisms of analgesia in mice and humans, Proc. Natl. Acad. Sci. U.S.A. 100 (2003) 4867-4872.

[64] A. Todorovic, J.R. Holder, J.W. Scott, C. Haskell-Luevano, Synthesis and activity of the melanocortin Xaa-d-Phe-ArgTrp-NH tetrapeptides with amide bond modifications, J. Pept. Res. 63 (2004) 270-278.

[65] K. Starowicz, B. Przewlocka, The role of melanocortins and their receptors in inflammatory processes, nerve regeneration and nociception, Life Sci. 73 (2003) 823-847.

[66] Q.H. Huang, V.J. Hruby, J.B. Tatro, Systemic alpha-MSH suppresses LPS fever via central melanocortin receptors independently of its suppression of corticosterone and IL-6 release, Am. J. Physiol. 275 (1998) R524-R530. 
[67] C. Mioni, D. Giuliani, M.M. Cainazzo, S. Leone, C. Iannone, C. Bazzani, P. Grieco, E. Novellino, A. Tomasi, A. Bertolini, S. Guarini, Further evidence that melanocortins prevent myocardial reperfusion injury by activating melanocortin MC3 receptors, Eur. J. Pharmacol. 477 (2003) 227234.

[68] J.J. Kuo, A.A. Silva, J.E. Hall, Hypothalamic melanocortin receptors and chronic regulation of arterial pressure and renal function, Hypertension 41 (2003) 768-774.

[69] J.M. Cerda-Reverter, H.B. Schioth, R.E. Peter, The central melanocortin system regulates food intake in goldfish, Regul. Pept. 115 (2003) 101-113.

[70] A.N. Verty, J.R. McFarlane, I.S. McGregor, P.E. Mallet, Evidence for an interaction between CB1 cannabinoid and melanocortin MCR-4 receptors in regulating food intake, Endocrinology 145 (2004) 3224-3231.

[71] H.C. Grossman, M.M. Hadjimarkou, R.M. Silva, S.Q. Giraudo, R.J. Bodnar, Interrelationships between mu opioid and melanocortin receptors in mediating food intake in rats, Brain Res. 991 (2003) 240-244.

[72] D.C. Albarado, J. McClaine, J.M. Stephens, R.L. Mynatt, J. Ye, A.W. Bannon, W.G. Richards, A.A. Butler, Impaired coordination of nutrient intake and substrate oxidation in melanocortin-4 receptor knockout mice, Endocrinology 145 (2004) 243-252.

[73] Y.X. Tao, D.L. Segaloff, Functional characterization of melanocortin-4 receptor mutations associated with childhood obesity, Endocrinology 144 (2003) 4544-4551.

[74] A.C. Foster, M. Joppa, S. Markison, K.R. Gogas, B.A. Fleck, B.J. Murphy, M. Wolff, M.J. Cismowski, N. Ling, V.S. Goodfellow, C. Chen, J. Saunders, P.J. Conlon, Body weight regulation by selective MC4 receptor agonists and antagonists, Ann. N. Y. Acad. Sci. 994 (2003) 103-110.

[75] P.A. Donohoue, Y.X. Tao, M. Collins, G.S. Yeo, S. O'Rahilly, D.L. Segaloff, Deletion of codons 88-92 of the melanocortin-4 receptor gene: a novel deleterious mutation in an obese female, J. Clin. Endocrinol. Metab. 88 (2003) 5841-5845.

[76] H. Biebermann, H. Krude, A. Elsner, V. Chubanov, T. Gudermann, A. Gruters, Autosomal-dominant mode of inheritance of a melanocortin- 4 receptor mutation in a patient with severe early-onset obesity is due to a dominant-negative effect caused by receptor dimerization, Diabetes 52 (2003) 29842988.

[77] Y. Konda, I. Gantz, J. DelValle, Y. Shimoto, H. Miwa, T. Yamada, Interaction of dual intracellular signaling pathways activated by the melanocortin-3 receptor, J. Biol. Chem. 269 (1994) 13162-13166.

[78] V. Chhajlani, Distribution of cDNA for melanocortin receptor subtypes in human tissues, Biochem. Mol. Biol. Int. 38 (1996) 73-80.

[79] S. Adachi, E. Morii, D. Kim, H. Ogihara, T. Jippo, A. Ito, Y.M. Lee, Y. Kitamura, Involvement of mi-transcription factor in expression of alpha-melanocyte-stimulating hormone receptor in cultured mast cells of mice, J. Immunol. 164 (2000) $855-860$

[80] W. Barcellini, G. Colombo, L. La Maestra, G. Clerici, L. Garofalo, A.T. Brini, J.M. Lipton, A. Catania, Alpha-melanocyte- stimulating hormone peptides inhibit HIV-1 expression in chronically infected promonocytic U1 cells and in acutely infected monocytes, J. Leukoc. Biol. 68 (2000) 693-699.

[81] A. Catania, G. Colombo, A. Carlin, L. Garofalo, S. Gatti, R. Buffa, N. Carboni, L. Ross, L. Santambrogio, L. Cantalamessa, J.M. Lipton, Autocrine inhibitory influences of alpha-melanocytes stimulating hormone in malignant pleural mesothelioma, J. Leukoc. Biol. 75 (2004) 253-259.

[82] G. Colombo, R. Buffa, M.T. Bardella, L. Garofalo, A. Carlin, J.M. Lipton, A. Catania, Anti-inflammatory effects of alphamelanocyte-stimulating hormone in celiac intestinal mucosa, Neuroimmunomodulation 10 (2002-2003) 208-216.

[83] D.M. Ignar, J.L. Andrews, M. Jansen, M.M. Eilert, H.M. Pink, P. Lin, R.G. Sherrill, J.R. Szewczyk, J.G. Conway, Regulation of TNF-alpha secretion by a specific melanocortin-1 receptor agonist, Peptides 24 (2003) 709-716.

[84] I. Gantz, H. Miwa, Y. Konda, Y. Shimoto, T. Tashiro, S.J. Watson, J. DelValle, T. Yamada, Molecular cloning, expression, and gene localization of a fourth melanocortin receptor, J. Biol. Chem. 268 (1993) 15174-15179.

[85] B.K. Rana, New insights into G-protein-coupled receptor signaling from the melanocortin receptor system, Mol. Pharmacol. 64 (2003) 1-4.

[86] T.J. Dexter, D.C. Bennett, Differentiation apparently repressed by the nucleus. Rapidly-induced pigmentation of enucleated melanoma cells, Exp. Cell. Res. 168 (1987) 255-264.

[87] K. Kameyama, P.M. Montague, V.J. Hearing, Expression of melanocyte-stimulating hormone receptors correlates with mammalian pigmentation, and can be modulated by interferons, J. Cell. Physiol. 137 (1988) 35-44.

[88] J.M. Pawelek, Factors regulating growth and pigmentation of melanoma cells, J. Invest. Dermatol. 66 (1976) 201-209.

[89] R. Halaban, S.H. Pomerantz, S. Marshall, D.T. Lambert, A.B. Lerner, Regulation of tyrosinase in human melanocytes grown in culture, J. Cell Biol. 97 (1983) 480-488.

[90] K.H. Kaidbey, K.H. Grove, A.M. Kligman, The influence of longwave ultraviolet radiation on sunburn cell production by UVB, J. Invest. Dermatol. 73 (1979) 743-745.

[91] K.H. Kaidbey, P.P. Agin, R.M. Sayre, A.M. Kligman, Photoprotection by melanin - a comparison of black and Caucasian skin, J. Am. Acad. Dermatol. 1 (1979) 249-260.

[92] G. Hunt, S. Kyne, K. Wakamatsu, S. Ito, A.J. Thody, Nle4DPhe7 alpha-melanocyte-stimulating hormone increases the eumelanin:phaeomelanin ratio in cultured human melanocytes, J. Invest. Dermatol. 104 (1995) 83-85.

[93] M.C. Scott, I. Suzuki, Z.A. Abdel-Malek, Regulation of the human melanocortin 1 receptor expression in epidermal melanocytes by paracrine and endocrine factors and by ultraviolet radiation, Pigment Cell Res. 15 (2002) 433-439.

[94] N.S. Ranadive, I.A. Menon, Role of reactive oxygen species and free radicals from melanins in photoinduced cutaneous inflammations, Pathol. Immunopathol. Res. 5 (1986) 118139.

[95] A.J. Thody, E.M. Higgins, K. Wakamatsu, S. Ito, S.A. Burchill, J.M. Marks, Pheomelanin as well as eumelanin is present in human epidermis, J. Invest. Dermatol. 97 (1991) 340-344. 
[96] A.B. Lerner, J.S. McGuire, Effect of alpha- and betamelanocyte-stimulating hormones on the skin colour of man, Naturwissenschaften 189 (1961) 176-179.

[97] N. Levine, S.N. Sheftel, T. Eytan, R.T. Dorr, M.E. Hadley, J.C. Weinrach, G.A. Ertl, K. Toth, D.L. McGee, V.J. Hruby, Induction of skin tanning by subcutaneous administration of a potent synthetic melanotropin, JAMA 266 (1991) 27302736.

[98] Z. Abdel-Malek, V.B. Swope, I. Suzuki, C. Akcali, M.D. Harriger, S.T. Boyce, K. Urabe, V.J. Hearing, Mitogenic and melanogenic stimulation of normal human melanocytes by melanotropic peptides, Proc. Natl. Acad. Sci. U.S.A. 92 (1995) 1789-1793.

[99] I. Suzuki, R.D. Cone, S. Im, J. Nordlund, Z.A. Abdel-Malek, Binding of melanotropic hormones to the melanocortin receptor MC1R on human melanocytes stimulates proliferation and melanogenesis, Endocrinology 137 (1996) 1627 1633 .

[100] H. Krude, H. Biebermann, W. Luck, R. Horn, G. Brabant, A. Gruters, Severe early-onset obesity, adrenal insufficiency and red hair pigmentation caused by POMC mutations in humans, Nat. Genet. 19 (1998) 155-157.

[101] S.J. Bultman, E.J. Michaud, R.P. Woychik, Molecular characterization of the mouse agouti locus, Cell 71 (1992) 1195-1204.

[102] S.E. Millar, M.W. Miller, M.E. Stevens, G.S. Barsh, Expression and transgenic studies of the mouse agouti gene provide insight into the mechanisms by which mammalian coat color patterns are generated, Development 121 (1995) 3223 3232.

[103] N. Matsunaga, V. Virador, C. Santis, W.D. Vieira, M. Furumura, J. Matsunaga, N. Kobayashi, V.J. Hearing, In situ localization of agouti signal protein in murine skin using immunohistochemistry with an ASP-specific antibody, Biochem. Biophys. Res. Commun. 270 (2000) 176-182.

[104] M.M. Ollmann, B.D. Wilson, Y.K. Yang, J.A. Kerns, Y. Chen, I. Gantz, G.S. Barsh, Antagonism of central melanocortin receptors in vitro and in vivo by agouti-related protein, Science 278 (1997) 135-138.

[105] W. Siegrist, R. Drozdz, R. Cotti, D.H. Willard, W.O. Wilkison, A.N. Eberle, Interactions of alpha-melanotropin and agouti on B16 melanoma cells: evidence for inverse agonism of agouti, J. Recept. Signal. Transduct. Res. 17 (1997) 75-98.

[106] C. Sakai, M. Ollmann, T. Kobayashi, Z. Abdel-Malek, J. Muller, W.D. Vieira, G. Imokawa, G.S. Barsh, V.J. Hearing, Modulation of murine melanocyte function in vitro by agouti signal protein, EMBO J. 16 (1997) 3544-3552.

[107] P.D. Donatien, G. Hunt, C. Pieron, J. Lunec, A. Taieb, A.J. Thody, The expression of functional MSH receptors on cultured human melanocytes, Arch. Dermatol. Res. 284 (1992) 424-426.

[108] D.C. Bennett, M.L. Lamoreux, The color loci of mice-a genetic century, Pigment Cell Res. 16 (2003) 333-344.

[109] T. Ha, L. Naysmith, K. Waterston, C. Oh, R. Weller, J.L. Rees, Defining the quantitative contribution of the melanocortin 1 receptor (MC1R) to variation in pigmentary phenotype, Ann. N. Y. Acad. Sci. 994 (2003) 339-347.
[110] L.S. Robbins, J.H. Nadeau, K.R. Johnson, M.A. Kelly, L. Roselli-Rehfuss, E. Baack, K.G. Mountjoy, R.D. Cone, Pigmentation phenotypes of variant extension locus alleles result from point mutations that alter MSH receptor function, Cell 72 (1993) 827-834.

[111] H. Klungland, D.I. Vage, L. Gomez-Raya, S. Adalsteinsson, $\mathrm{S}$. Lien, The role of melanocyte-stimulating hormone (MSH) receptor in bovine coat color determination, Mamm. Genome 6 (1995) 636-639.

[112] J.M. Newton, A.L. Wilkie, L. He, S.A. Jordan, D.L. Metallinos, N.G. Holmes, I.J. Jackson, G.S. Barsh, Melanocortin 1 receptor variation in the domestic dog, Mamm. Genome 11 (2000) 24-30.

[113] F. Rouzaud, J. Martin, P.F. Gallet, D. Delourme, V. GoulemotLeger, Y. Amigues, F. Menissier, H. Leveziel, R. Julien, A. Oulmouden, A first genotyping assay of French cattle breeds based on a new allele of the extension gene encoding the melanocortin-1 receptor (MC1R), Genet. Sel. E 32 (2000) $511-520$

[114] L. Marklund, M.J. Moller, K. Sandberg, L. Andersson, A missense mutation in the gene for melanocyte-stimulating hormone receptor $(\mathrm{MC} 1 \mathrm{R})$ is associated with the chestnut coat color in horses, Mamm. Genome 7 (1996) 895-899.

[115] P. Valverde, E. Healy, I. Jackson, J.L. Rees, A.J. Thody, Variants of the melanocyte-stimulating hormone receptor gene are associated with red hair and fair skin in humans, Nat. Genet. 11 (1995) 328-330.

[116] R. Smith, E. Healy, S. Siddiqui, N. Flanagan, P.M. Steijlen, I. Rosdahl, J.P. Jacques, S. Rogers, R. Turner, I.J. Jackson, M.A. Birch-Machin, J.L. Rees, Melanocortin 1 receptor variants in an Irish population, J. Invest. Dermatol. 111 (1998) 119122.

[117] N. Flanagan, A.J. Ray, C. Todd, M.A. Birch-Machin, J.L. Rees, The relation between melanocortin 1 receptor genotype and experimentally assessed ultraviolet radiation sensitivity, J. Invest. Dermatol. 117 (2001) 1314-1317.

[118] E. Healy, N. Flannagan, A. Ray, C. Todd, I.J. Jackson, J.N. Matthews, M.A. Birch-Machin, J.L. Rees, Melanocortin-1receptor gene and sun sensitivity in individuals without red hair, Lancet 355 (2000) 1072-1073.

[119] M. Bastiaens, J. ter Huurne, N. Gruis, W. Bergman, R. Westendorp, B.J. Vermeer, J.N. Bouwes Bavinck, The melanocortin1-receptor gene is the major freckle gene, Hum. Mol. Genet. 10 (2001) 1701-1708.

[120] N.F. Box, J.R. Wyeth, L.E. O'Gorman, N.G. Martin, R.A. Sturm, Characterization of melanocyte-stimulating hormone receptor variant alleles in twins with red hair, Hum. Mol. Genet. 6 (1997) 1891-1897.

[121] J.S. Palmer, D.L. Duffy, N.F. Box, J.F. Aitken, L.E. O'Gorman, A.C. Green, N.K. Hayward, N.G. Martin, R.A. Sturm, Melanocortin-1 receptor polymorphisms and risk of melanoma: is the association explained solely by pigmentation phenotype? Am. J. Hum. Genet. 66 (2000) 176186.

[122] N.F. Box, D.L. Duffy, R.E. Irving, A. Russell, W. Chen, L.R. Griffyths, P.G. Parsons, A.C. Green, R.A. Sturm, Melanocortin-1 receptor genotype is a risk factor for basal 
and squamous cell carcinoma, J. Invest. Dermatol. 116 (2001) 224-229.

[123] C. Kennedy, J. ter Huurne, M. Berkhout, N. Gruis, M. Bastiaens, W. Bergman, R. Willemze, J.N. Bavinck, Melanocortin 1 receptor $(\mathrm{MC} 1 \mathrm{R})$ gene variants are associated with an increased risk for cutaneous melanoma which is largely independent of skin type and hair color, J. Invest. Dermatol. 117 (2001) 294-300.

[124] N.F. Box, D.L. Duffy, W. Chen, M. Stark, N.G. Martin, R.A. Sturm, N.K. Hayward, MC1R genotype modifies risk of melanoma in families segregating CDKN2A mutations, Am. J. Hum. Genet. 69 (2001) 765-773.

[125] J.M. Bliss, D. Ford, A.J. Swerdlow, B.K. Armstrong, M. Cristofolini, J.M. Elwood, A. Green, E.A. Holly, T. Mack, R.M. MacKie, A. Osterlind, S.D. Walter, J. Peto, D.F. Easton, Risk of cutaneous melanoma associated with pigmentation characteristics and freckling: systematic overview of 10 casecontrol studies. The International Melanoma Analysis Group (IMAGE), Int. J. Cancer. 62 (1995) 367-376.

[126] P. Valverde, E. Healy, S. Sikkink, F. Haldane, A.J. Thody, A. Carothers, I.J. Jackson, J.L. Rees, The Asp84Glu variant of the melanocortin 1 receptor (MC1R) is associated with melanoma, Hum. Mol. Genet. 5 (1996) 1663-1666.

[127] E. Healy, C. Todd, I.J. Jackson, M. Birch-Machin, J.L. Rees, Skin type, melanoma, and melanocortin 1 receptor variants, J. Invest. Dermatol. 112 (1999) 512-513.

[128] F. Ichii-Jones, J.T. Lear, A.H. Heagerty, A.G. Smith, P.E. Hutchinson, J. Osborne, B. Bowers, P.W. Jones, E. Davies, W.E. Ollier, W. Thomson, L. Yengi, J. Bath, A.A. Fryer, R.C. Strange, Susceptibility to melanoma: influence of skin type and polymorphism in the melanocyte-stimulating hormone receptor gene, J. Invest. Dermatol. 111 (1998) 218221.

[129] J.H. Leonard, L.H. Marks, W. Chen, A.L. Cook, G.M. Boyle, D.J. Smit, D.L. Brown, J.L. Stow, P.G. Parsons, R.A. Sturm, Screening of human primary melanocytes of defined melanocortin-1 receptor genotype: pigmentation marker, ultrastructural and UV-survival studies, Pigment Cell Res. 16 (2003) 198-207.

[130] R.A. Sturm, R.D. Teasdale, N.F. Box, Human pigmentation genes: identification, structure and consequences of polymorphic variation, Gene 277 (2001) 49-62.

[131] J.V. Schaffer, J.L. Bolognia, The melanocortin-1 receptor: red hair and beyond, Arch. Dermatol. 137 (2001) 1477-1485.

[132] P.A. Frandberg, M. Doufexis, S. Kapas, V. Chhajlani, Human pigmentation phenotype: a point mutation generates nonfunctional MSH receptor, Biochem. Biophys. Res. Commun. 245 (1998) 490-492.

[133] H.B. Schioth, S.R. Phillips, R. Rudzish, M.A. Birch-Machin, J.E. Wikberg, J.L. Rees, Loss of function mutations of the human melanocortin 1 receptor are common and are associated with red hair, Biochem. Biophys. Res. Commun. 260 (1999) 488-491.

[134] C. Jimenez-Cervantes, C. Olivares, P. Gonzalez, R. Morandini, G. Ghanem, J.C. Garcia-Borron, The Pro162 variant is a lossof-function mutation of the human melanocortin 1 receptor gene, J. Invest. Dermatol. 117 (2001) 156-158.
[135] C. Jimenez-Cervantes, S. Germer, P. Gonzalez, J. Sanchez, C.O. Sanchez, J.C. Garcia-Borron, Thr40, Met122 are new partial loss-of-function natural mutations of the human melanocortin 1 receptor, FEBS Lett. 508 (2001) 44-48.

[136] R.A. Sturm, D.L. Duffy, N.F. Box, W. Chen, D.J. Smit, D.L. Brown, J.L. Stow, J.H. Leonard, N.G. Martin, The role of melanocortin-1 receptor polymorphism in skin cancer risk phenotypes, Pigment Cell Res. 16 (2003) 266-272.

[137] R.A. Sturm, Skin colour and skin cancer: MC1R, the genetic link, Melanoma Res. 12 (2002) 405-416.

[138] P.A. van der Velden, L.A. Sandkuijl, W. Bergman, S. Pavel, L. van Mourik, R.R. Frants, N.A. Gruis, Melanocortin-1 receptor variant $\mathrm{R} 151 \mathrm{C}$ modifies melanoma risk in Dutch families with melanoma, Am. J. Hum. Genet. 69 (2001) 774-779.

[139] A.K. Chakraborty, Y. Funasaka, A. Slominski, G. Ermak, J. Hwang, J.M. Pawelek, M. Ichihashi, Production and release of proopiomelanocortin (POMC) derived peptides by human melanocytes and keratinocytes in culture: regulation by ultraviolet B, Biochim. Biophys. Acta 1313 (1996) 130-138.

[140] I. Suzuki, T. Kato, T. Motokawa, Y. Tomita, E. Nakamura, T. Katagiri, Increase of pro-opiomelanocortin mRNA prior to tyrosinase, tyrosinase-related protein 1, dopachrome tautomerase, Pmel-17/gp100, and P-protein mRNA in human skin after ultraviolet B irradiation, J. Invest. Dermatol. 118 (2002) 73-78.

[141] G. Imokawa, Y. Yada, M. Miyagishi, Endothelins secreted from human keratinocytes are intrinsic mitogens for human melanocytes, J. Biol. Chem. 267 (1992) 24675-24680.

[142] R. Halaban, R. Langdon, N. Birchall, C. Cuono, A. Baird, G. Scott, G. Moellmann, J. McGuire, Basic fibroblast growth factor from human keratinocytes is a natural mitogen for melanocytes, J. Cell Biol. 107 (1988) 1611-1619.

[143] D. Barker, K. Dixon, E.E. Medrano, D. Smalara, S. Im, D. Mitchell, G. Babcock, Z.A. Abdel-Malek, Comparison of the responses of human melanocytes with different melanin contents to ultraviolet B irradiation, Cancer Res. 55 (1995) 4041-4046.

[144] K. Wakamatsu, A. Graham, D. Cook, A.J. Thody, Characterisation of ACTH peptides in human skin and their activation of the melanocortin-1 receptor, Pigment Cell Res. 10 (1997) 288-297.

[145] J. Bolognia, M. Murray, J. Pawelek, UVB-induced melanogenesis may be mediated through the MSH-receptor system, J. Invest. Dermatol. 92 (1989) 651-656.

[146] J.M. Pawelek, A.K. Chakraborty, M.P. Osber, S.J. Orlow, K.K. Min, K.E. Rosenzweig, J.L. Bolognia, Molecular cascades in UV-induced melanogenesis: a central role for melanotropins? Pigment Cell Res. 5 (1992) 348-356.

[147] A. Tada, E. Pereira, D. Beitner-Johnson, R. Kavanagh, Z.A. Abdel-Malek, Mitogen- and ultraviolet-B-induced signaling pathways in normal human melanocytes, J. Invest. Dermatol. 118 (2002) 316-322.

[148] I.I. Geschwind, R.A. Huseby, R. Nishioka, The effect of melanocyte-stimulating hormone on coat color in the mouse, Recent Prog. Horm. Res. 28 (1972) 91-130.

[149] H.B. Tamate, T. Takeuchi, Action of the e locus of mice in the response of phaeomelanic hair follicles to alpha-melanocyte- 
stimulating hormone in vitro, Science 224 (1984) 12411242.

[150] M.J. Marinissen, J.S. Gutkind, G-protein-coupled receptors and signaling networks: emerging paradigms, Trends Pharmacol. Sci. 22 (2001) 368-376.

[151] W. Englaro, R. Rezzonico, M. Durand-Clement, D. Lallemand, J.P. Ortonne, R. Ballotti, Mitogen-activated protein kinase pathway and AP-1 are activated during cAMP-induced melanogenesis in B-16 melanoma cells, J. Biol. Chem. 270 (1995) 24315-24320.

[152] V.J. Hearing, K. Tsukamoto, Enzymatic control of pigmentation in mammals, FASEB J. 5 (1991) 2902-2909.

[153] J.L. Rees, The melanocortin 1 receptor (MC1R): more than just red hair, Pigment Cell Res. 13 (2000) 135-140.

[154] D.L. Duffy, N.F. Box, W. Chen, J.S. Palmer, G.W. Montgomery, M.R. James, N.K. Hayward, N.G. Martin, R.A. Sturm, Interactive effects of MC1R and OCA2 on melanoma risk phenotypes, Hum. Mol. Gen. 13 (2004) 447-461.

[155] A. Tada, I. Suzuki, S. Im, M.B. Davis, J. Cornelius, G. Babcock, J.J. Nordlund, Z.A. Abdel-Malek, Endothelin-1 is a paracrine growth factor that modulates melanogenesis of human melanocytes and participates in their responses to ultraviolet radiation, Cell Growth Differ. 9 (1998) 575584.

[156] G. Hunt, C. Todd, S. Kyne, A.J. Thody, ACTH stimulates melanogenesis in cultured human melanocytes, J. Endocrinol. 140 (1994) R1-R3.

[157] A. Chakraborty, J. Pawelek, MSH receptors in immortalized human epidermal keratinocytes: a potential mechanism for coordinate regulation of the epidermal-melanin unit, J. Cell Physiol. 157 (1993) 344-350.

[158] E. Aberdam, P. Auberger, J.P. Ortonne, R. Ballotti, Neprilysin, a novel target for ultraviolet $B$ regulation of melanogenesis via melanocortins, J. Invest. Dermatol. 115 (2000) 381-387.

[159] R. Busca, R. Ballotti, Cyclic AMP a key messenger in the regulation of skin pigmentation, Pigment Cell Res. 13 (2000) 60-69.

[160] C. Romero-Graillet, E. Aberdam, M. Clement, J.P. Ortonne, R. Ballotti, Nitric oxide produced by ultraviolet-irradiated keratinocytes stimulates melanogenesis, J. Clin. Invest. 99 (1997) 635-642.

[161] P.R. Gordon, C.P. Mansur, B.A. Gilchrest, Regulation of human melanocyte growth, dendricity, and melanization by keratinocyte derived factors, J. Invest. Dermatol. 92 (1989) $565-572$.

[162] Z.A. Abdel-Malek, V.B. Swope, N. Amornsiripanitch, J.J. Nordlund, In vitro modulation of proliferation and melanization of S 91 melanoma cells by prostaglandins, Cancer Res. 47 (1987) 3141-3146.

[163] G. Hunt, C. Todd, J.E. Cresswell, A.J. Thody, Alphamelanocyte-stimulating hormone and its analogue Nle4DPhe 7 alpha-MSH affect morphology, tyrosinase activity and melanogenesis in cultured human melanocytes, J. Cell Sci. 107 (1994) 205-211.

[164] M. Hara, M. Yaar, B.A. Gilchrest, Endothelin-1 of keratinocyte origin is a mediator of melanocyte dendricity, J. Invest. Dermatol. 105 (1995) 744-748.
[165] J.J. Yohn, J.G. Morelli, S.J. Walchak, K.B. Rundell, D.A. Norris, M.R. Zamora, Cultured human keratinocytes synthesize and secrete endothelin-1, J. Invest. Dermatol. 100 (1993) $23-26$.

[166] S. Im, O. Moro, F. Peng, E.E. Medrano, J. Cornelius, G. Babcock, J.J. Nordlund, Z.A. Abdel-Malek, Activation of the cyclic AMP pathway by alpha-melanotropin mediates the response of human melanocytes to ultraviolet B radiation, Cancer Res. 58 (1998) 47-54.

[167] T.S. Kupper, A.O. Chua, P. Flood, J. McGuire, U. Gubler, Interleukin 1 gene expression in cultured human keratinocytes is augmented by ultraviolet irradiation, J. Clin. Invest. 80 (1987) 430-436.

[168] G. Imokawa, M. Miyagishi, Y. Yada, Endothelin-1 as a new melanogen: coordinated expression of its gene and the tyrosinase gene in UVB-exposed human epidermis, J. Invest. Dermatol. 105 (1995) 32-37.

[169] H. Dudek, S.R. Datta, T.F. Franke, M.J. Birnbaum, R. Yao, G.M. Cooper, R.A. Segal, D.R. Kaplan, M.E. Greenberg, Regulation of neuronal survival by the serine-threonine protein kinase Akt, Science 275 (1997) 661-665.

[170] G. Kulik, A. Klippel, M.J. Weber, Anti-apoptotic signalling by the insulin-like growth factor I, PI3K, and Akt, Mol. Cell. Biol. 17 (1997) 1595-1606.

[171] M. Mildner, L. Eckhart, B. Lengauer, E. Tschachler, Hepatocyte growth factor/scatter factor inhibit UVB-induced apoptosis of human keratinocytes but not of keratinocytes derived cell lines via the PI3K/Akt pathway, J. Biol. Chem. 277 (2002) 14146-14152.

[172] J.A. Romashkova, S.S. Makarov, NF-kappa B is a target of Akt in anti-apoptotic PDGF signalling, Nature 401 (1999) 8690.

[173] Y.S. Wan, Z.Q. Wang, Y. Shao, J.J. Voorhees, G.J. Fisher, UVR activates PI3K/AKT survival pathway via EGF receptors in human skin in vivo, Int. J. Oncol. 18 (2001) 461-466.

[174] R. Yao, G.M. Cooper, Requirement for PI3K in the prevention of apoptosis by nerve growth factor, Science 267 (1995) 2003-2006.

[175] M.H. Cardone, N. Roy, H.R. Stennicke, G.S. Salvesen, T.F. Franke, E. Stanbridge, S. Frisch, J.C. Reed, Regulation of cell death protease caspase- 9 by phosphorylation, Science 282 (1998) 1318-1321.

[176] N. Filippa, C.L. Sable, C. Filloux, B. Hemmings, E. Van Obberghen, Mechanism of protein kinase B activation by cyclic AMP-dependent protein kinase, Mol. Cell. Biol. 9 (1999) 4989-5000.

[177] M. Wu, T.J. Hemesath, C.M. Takemoto, M.A. Horstmann, A.G. Wells, E.R. Price, D.Z. Fisher, D.E. Fisher, C-kit triggers dual phosphorylations, which couple activation and degradation of the essential melanocyte factor Mi, Genes Dev. 14 (2000) 301-312.

[178] M. Bohm, G. Moellmann, E. Cheng, M. Alvarez-Franco, S. Wagner, P. Sassone-Corsi, R. Halaban, Identification of p90RSK as the probable CREB-Ser133 kinase in human melanocytes, Cell Growth Differ. 6 (1995) 291-302.

[179] M.J. Hoogduijn, E. Cemeli, K. Ross, D. Anderson, A.J. Thody, J.M. Wood, Melanin protects melanocytes and keratinocytes 
against $\mathrm{H}_{2} \mathrm{O}_{2}$-induced DNA strand breaks through its ability to bind $\mathrm{Ca}^{2+}$, Exp. Cell Res. 294 (2004) 60-67.

[180] G. Murphy, A.R. Young, H.C. Wulf, D. Kulms, T. Schwarz, The molecular determinants of sunburn cell formation, Exp. Dermatol. 10 (2001) 155-160.

[181] E. Sage, Distribution and repair of photolesions in DNA: genetic consequences and the role of sequence context, Photochem. Photobiol. 57 (1993) 163-174.

[182] T. Tadokoro, N. Kobayashi, B.Z. Zmudzka, S. Ito, K. Wakamatsu, Y. Yamaguchi, K.S. Korossy, S.A. Miller, J.Z. Beer, V.J. Hearing, UV-induced DNA damage and melanin content in human skin differing in racial/ethnic origin, FASEB J. 17 (2003) 1177-1179.

[183] B.S. Rosenstein, D.L. Mitchell, Action spectra for the induction of 6-4 PP and CPD in normal human skin fibroblasts, Photochem. Photobiol. 45 (1987) 775-780.

[184] J. Cadet, T. Douki, J.P. Pouget, J.L. Ravanat, Singlet oxygen DNA damage products: formation and measurements, Methods Enzymol. 319 (2000) 143-153.

[185] K.C. Cheng, D.S. Cahill, H. Kasai, S. Nishimura, L.A. Loeb, 8-Hydroxyguanine, an abundant form of oxidative DNA damage causes $\mathrm{G}$ to $\mathrm{T}$ and A to $\mathrm{C}$ substitution, J. Biol. Chem. 267 (1992) 166-172.

[186] P.J. Rochette, J.P. Therrien, R. Drouin, D. Perdiz, N. Bastien, E.A. Drobetsky, E. Sage, UVA-induced cyclobutane pyrimidine dimers form predominantly at thymine-thymine dipyrimidines and correlate with mutation spectrum in rodent cells, Nucleic Acids Res. 11 (2003) 27862794.

[187] B.S. Thoma, K.M. Vasquez, Critical DNA damage recognition functions of XPC-hHR23B and XPA-RPA in nucleotide excision repair, Mol. Carcinog. 38 (2003) 1-13.

[188] A.M. Sijbers, W.L. de Laat, R.R. Ariza, M. Biggerstaff, Y.F. Wei, J.C. Moggs, K.C. Carter, B.K. Shell, G. Evans, M.C. de Jong, S. Rademakers, J. de Rooij, N.G. Jaspers, J.H. Hoeijmakers, R.D. Wood, Xeroderma pigmentosum group F caused by a defect in a structure-specific DNA repair endonuclease, Cell 86 (1996) 811-822.

[189] A. Schwarz, S. Stander, M. Berneburgt, M. Bohm, D. Kulms, H. van Steegt, K. Grosse-Heitmeyer, J. Krutmannt, T. Schwarz, Interleukin-12 supresses ultraviolet radiationinduced apoptosis by inducing DNA repair, Nat. Cell Biol. 4 (2002) 26-31.

[190] S. Fan, Y.X. Ma, J.A. Wang, R.Q. Yuan, Q. Meng, Y. Cao, J.J. Laterra, I.D. Goldberg, E.M. Rosen, The cytokine hepatocyte growth factor/scatter factor inhibits apoptosis and enhances DNA repair by a common mechanism involving signaling through phosphatidyl inositol $3^{\prime}$ kinase, Oncogene 19 (2000) 2212-2223.

[191] M.L. Kripke, C.G. Munn, A. Jeevan, J.M. Tang, C. Bucana, Evidence that cutaneous antigen presenting cells migrate to regional lymph nodes during contact sensitization, J. Immunol. 145 (1990) 2833-2838.

[192] F.M. Rattis, J. Peguet-Navarro, P. Courtellemont, G. Redziniak, D. Schmitt, In vitro effects of ultraviolet B radiation on human Langerhan cell antigen-presenting function, Cell. Immunol. 164 (1995) 65-72.
[193] J.C. Simon, J. Krutmann, C.A. Elmets, P.R. Bergstresser, P.D. Cruz, Ultraviolet B-irradiated antigen-presenting cells display altered accessory signaling for T-cell activation: relevance to immune responses initiated in skin, J. Invest. Dermatol. 98 (1992) 66S-69S.

[194] F.P. Noonan, E.C. De Fabo, Immunosuppression by ultraviolet $\mathrm{B}$ radiation: initiation by urocanic acid, Immunol. Today 13 (1992) 250-254.

[195] C.A. Elmets, P.R. Bergstresser, R.E. Tigelaar, P.J. Wood, J.W. Streilein, Analysis of the mechanism of unresponsiveness produced by haptens painted on skin exposed to low dose ultraviolet radiation, J. Exp. Med. 158 (1983) 781794.

[196] T. Yoshikawa, V. Rae, W. Bruins-Slot, J.W. Van den Berg, J.R. Taylor, J.W. Streilein, Susceptibility to effect of UVB radiation on induction of contact hypersensitivity as a risk factor for skin cancer in humans, J. Invest. Dermatol. 95 (1990) 530536.

[197] M.S. Fisher, M.L. Kripke, Systemic alteration induced in mice by UVR and its relationship to UV carcinogenesis, Proc. Natl. Acad. Sci. U.S.A. 74 (1977) 1688-1692.

[198] P. Scott, IL-12: initiation cytokine for cell-mediated immunity, Science 260 (1993) 496-497.

[199] C. Nishigori, D.B. Yarosh, S.E. Ullrich, A.A. Vink, C.D. Bucana, L. Roza, M.L. Kripke, Evidence that DNA damage triggers interleukin 10 cytokine production in UV-irradiated murine keratinocytes, Proc. Natl. Acad. Sci. U.S.A. 93 (1996) 10354-10359.

[200] A.J. McKnight, G.J. Zimmer, I. Fogelman, S.F. Wolf, A.K. Abbas, Effects of IL-12 on helper T cell-dependent immune responses in vivo, J. Immunol. 152 (1994) 21722179.

[201] V. Chhajlani, J.E.S. Wikberg, Molecular cloning and expression of the human melanocyte-stimulating hormone receptor cDNA, FEBS Lett. 309 (1992) 417-420.

[202] R.A. Star, N. Rajora, J. Huang, R.C. Stock, A. Catania, J.M. Lipton, Evidence of autocrine modulation of macrophage nitric oxide synthase by $\alpha$-melanocyte-stimulating hormone, Proc. Natl. Acad. Sci. U.S.A. 92 (1995) 80168020.

[203] M. Hartmeyer, T. Scholzen, E. Becher, R.S. Bhardwaj, T. Schwarz, T.A. Luger, Human dermal microvascular endothelial cells express the melanocortin receptor type I and produce levels of IL-8 upon stimulation with alpha-melanocytestimulating hormone, J. Immunol. 159 (1997) 19301937.

[204] A. Catania, N. Rajora, F. Capsoni, F. Minonzio, R.A. Star, J.M. Lipton, The neuropeptide $\alpha$-MSH has specific receptors on neutrophils and reduces chemotaxis in vitro, Peptides 17 (1996) 675-679.

[205] E. Becher, K. Mahnke, T. Brzoska, D.H. Kalden, S. Grabbe, T.A. Luger, Human peripheral blood derived dendritic cells express functional melanocortin receptor MC1R, Ann. N. Y. Acad. Sci. 885 (1999) 188-195.

[206] T.A. Luger, T. Scholzen, S. Grabbe, The role of $\alpha$-melanocytestimulating hormone in cutaneous biology, J. Invest. Dermatol. Symp. Proc. 2 (1997) 87-93. 
[207] S. Grabbe, R.S. Bhardwaj, K. Mahnke, M.M. Simon, T. Schwarz, T.A. Luger, $\alpha$-Melanocyte-stimulating hormone induces hapten-specific tolerance in mice, J. Immunol. 156 (1996) 473-478.

[208] A. Catania, J.W. Lipton, $\alpha$-Melanocyte-stimulating hormone in the modulation of host reactions, Endocr. Rev. 14 (1993) 564-576.
[209] J.E. Wikberg, R. Muceniece, I. Mandrika, P. Prusis, J. Lindblom, C. Post, A. Skottner, New aspects on the melanocortins and their receptors, Pharmacol. Res. 42 (2000) 393-420.

[210] N. Rajora, G. Boccoli, D. Burns, S. Sharma, A.P. Catania, J.M. Lipton, $\alpha$-MSH modulates local and circulating TNF- $\alpha$ in experimental brain inflammation, J. Neurosci. 17 (1997) 2181-2186. 